
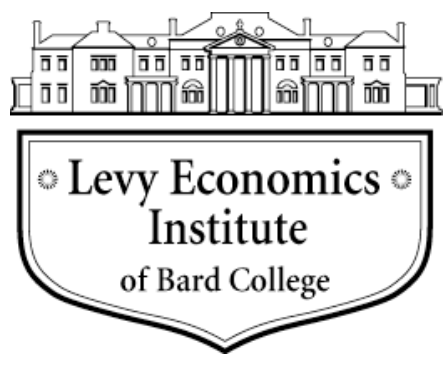

Working Paper No. 722

\title{
Guaranteed Green Jobs: Sustainable Full Employment
}

by

\author{
Antoine Godin* \\ University of Pavia
}

May 2012

\begin{abstract}
*E-mail: godin.antoine@gmail.com. I thank Marco Missaglia, Stephen Kinsella, and Codrina Rada, and the participants in the "17th Workshop on Alternative Economic Policy in Europe" for helpful conversations and comments. All errors remain mine.
\end{abstract}

The Levy Economics Institute Working Paper Collection presents research in progress by Levy Institute scholars and conference participants. The purpose of the series is to disseminate ideas to and elicit comments from academics and professionals.

Levy Economics Institute of Bard College, founded in 1986, is a nonprofit, nonpartisan, independently funded research organization devoted to public service. Through scholarship and economic research it generates viable, effective public policy responses to important economic problems that profoundly affect the quality of life in the United States and abroad.

\author{
Levy Economics Institute \\ P.O. Box 5000 \\ Annandale-on-Hudson, NY 12504-5000 \\ http://www.levyinstitute.org
}

Copyright (C Levy Economics Institute 2012 All rights reserved

ISSN 1547-366X 


\begin{abstract}
In most economies, the potential of saving energy via insulation and more efficient uses of electricity is important. In order to reach the Kyoto Protocol objectives, it is urgent to develop policies that reduce the production of carbon dioxide in all sectors of the economy. This paper proposes an analysis of a green-jobs employer-of-last-resort (ELR) program based on a stockflow consistent (SFC) model with three productive sectors (consumption, capital goods, and energy) and two household sectors (wage earners and capitalists). By increasing the energy efficiency of dwellings and public buildings, the green-jobs ELR sector implies a shift in consumption patterns from energy consumption toward consumption of goods. This could spur the private sector and thus increase employment. Lastly, the jobs guarantee program removes all involuntary unemployment and decreases poverty while lowering carbon dioxide emissions. The environmental policy proposed in this paper is macroeconomic and offers a structural change of the economy instead of the usual micro solutions.
\end{abstract}

Keywords: Full Employment; Green Jobs; Stock-flow Consistent

JEL Classifications: E24, J08, Q48 


\section{GUARANTEED JOBS AND THE KYOTO PROTOCOL}

Unemployment is a fact in present economies. Even without a crisis, unemployment exists and costs a lot to society. Reasons for unemployment are multiple and differ according to the theory at hand. Lack of effective demand, imperfect markets, and frictions are examples of unemployment justifications. All sorts of policies based on these different theories have been implemented with various results, but none has proven to tackle unemployment. Full employment has never been achieved during the last 40 years. Often the problem is that these policies promote indirect job creation: public spending, wage subsidies, incentives, tax cuts, or job training. Another issue is the change in the dimension of these policies; we have now microeconomic supply of labor policies instead of macroeconomic demand stimulation policies. Even if they meet some objectives, these policies do not provide an answer to unemployment.

It is of the duty of the state, as Lerner expressed it, to provide jobs when the market fails to do so (Lerner 1944, 1951). By guaranteeing jobs to all who are willing and able to work, the state would remove all involuntary unemployment. Examples of such job guarantee schemes exist, even if never developed on a full scale ${ }^{1}$ (see Forstater 1998; Mitchell 2007; Mitchell and Muyskens 2008; Wray 1998, 2007 for different proposals and analysis).

"Green jobs reduce the environmental impact of enterprises and economic sectors, ultimately to levels that are sustainable" (UNEP 2008). In order to reach the Kyoto Protocol objectives, it is urgently necessary to develop policies that reduce the production of carbon dioxide. Papers connecting the dots between the need for a structural change in productive sectors toward a low-carbon economy and the need for a job guarantee are numerous (see Forstater 2006; Lieuw-Kie-Song 2009, 2010; UNEP 2007, 2008, among others). The job guarantee schemes analyzed in this paper focus on green jobs aiming at energy efficiency in buildings and constructions.

This paper presents a stock flow consistent model of a multi-sectorial economy with an employer-of-last-resort (ELR) scheme where ELR workers would work to transform the economy toward a greener one. We will focus on the impact of the green job ELR policy and compare these results with a standard Keynesian demand spur.

\footnotetext{
${ }^{1}$ The National Rural Employment Guarantee Act in India and the plan Jefes y Jefas de Hogar Desocupados in Argentina are examples of such policies (UNCTAD 2010; Kostzer 2008).
} 


\subsection{Overview of the Model}

Stock-flow consistent (SFC) models are based on the works of two schools of thoughts developed by Wynne Godley and James Tobin. Both these approaches are centered on the importance of consistency between stocks and flows: each flow in the model comes from a sector (or account) and goes to another account. In each period, the sum of flows has to be nil. Stocks are the sum of inflows and outflows. SFC models are thus evolutionary models (Godley and Lavoie 2007).

The economy modeled in this paper is composed of two household sectors (wage earners and capitalists), three productive sectors (capital goods, energy, and widgets), a banking sector, and a public sector. Figure 1 represents the flow diagram of the model. Both household sectors and the public sector consume widgets and electricity (thin dashed lines on the diagram). Furthermore, all productive sectors consume energy to produce their own goods. All productive sectors use fixed capital (produced by the capital good sector; thin dash-dotted line) and labor (thick solid line). In order to invest, firms borrow money from banks and pay interests (thick dotted line). Finally, industries pay wages to workers (thick solid line) and dividends to capitalists (thick dashed line). Households sectors save part of their wealth as cash on their current account (thin solid lines) and as bonds (thick dash-dotted lines) for which they receive interests. Banks balance their liabilities (current accounts) with loans to firms and bond holding (thin dotted line) for which they receive interests. The government imposes a tax on wages and profits (thick dash-dotted lines), pays interests on bonds, and gives a dole to unemployed workers. 
Figure 1. Flow diagram: each line represents a group of flows between two sectors. Each group of flows might be bi-directional. For example, the line linking wage earners and government represents flows from wage earners to government (taxes, bond holding) and flows from government to wage earners (dole, interests on bonds).

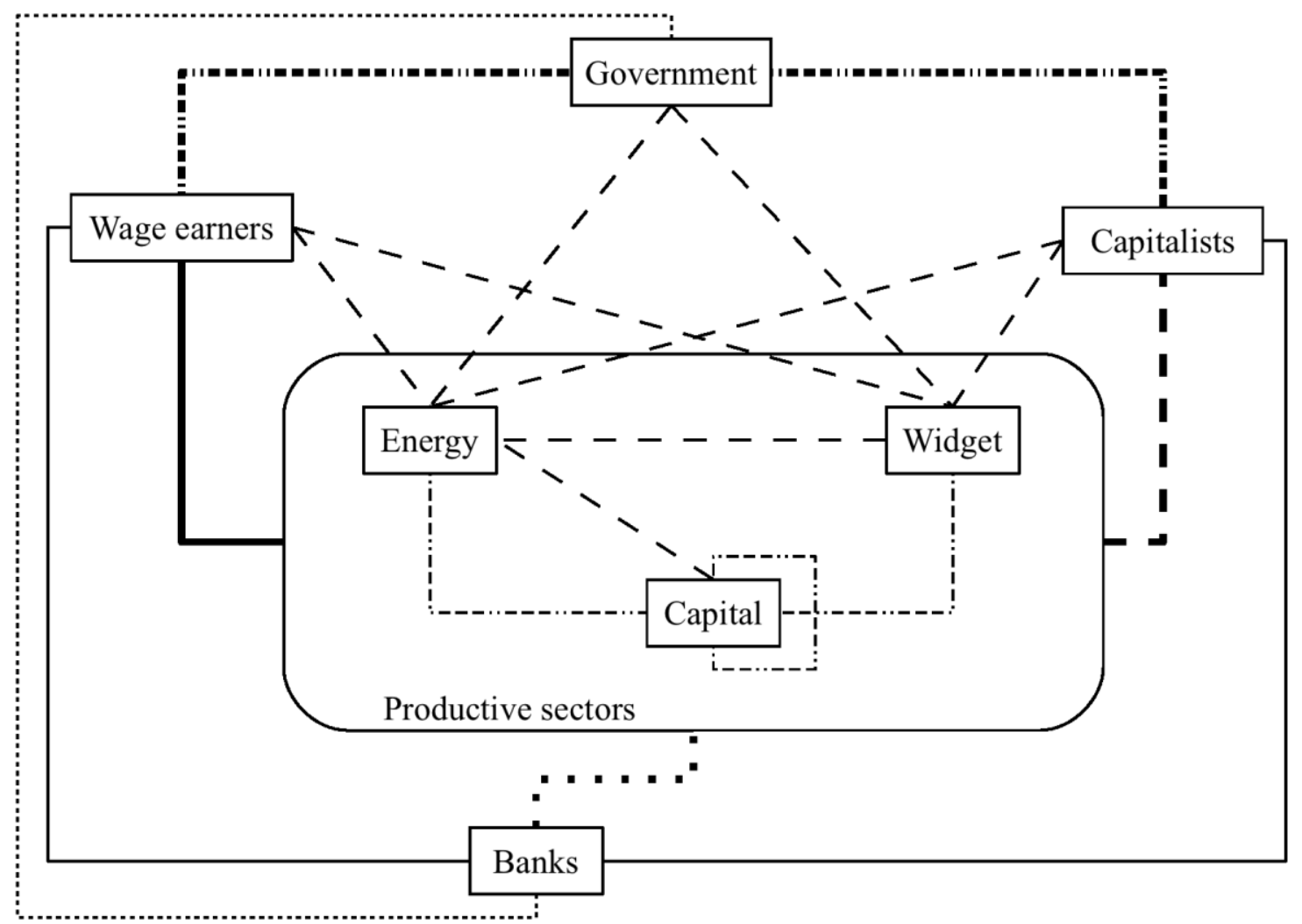

This paper is structured as follows. Section 2 will analyze structural unemployment and the policies implemented in order to reduce it. Sections 3 and 4 will present the multi-sectorial model and its steady state. The ELR scheme and its impacts are studied in section 5. Finally, section 6 concludes.

\section{UNEMPLOYMENT}

Mainstream economics usually explains unemployment by market rigidities. Unemployment would disappear if wages were allowed to decline low enough. Labor market is like all other good markets with rigid prices and should not be seen as anything else.

However, unemployment is not often recognized for the function it has in a capitalist economy (Forstater 1998, 2006). Most of the time, firms are working with excess capacity in order to be able to respond to sudden changes in demand. Unemployment thus allows the economy to be more flexible by permitting firms to hire workers out of the "reserve army of labor" when needed. 
Following Schumpeterian creative destruction, the process of the birth of new technologies creates unemployment in obsolete sectors while creating jobs in new sectors (Schumpeter 1934/1912). Structural unemployment may also be explained as a mismatch between demand and supply. Pasinetti (1993) shows that it is highly improbable that, in a multisectorial model, distribution of demand among different sectors is such that full employment prevails, even when aggregate demand is high enough to imply full employment.

Ros (2000) explains using various two-sectors models that labor surplus economies arise for different reasons. He uses efficiency wages on top of a Lewis growth model to show how Kaldorian underemployment appears. ${ }^{2}$ In chapter 11 , he also shows how unemployment emerges out of constrained economies, using a Kaleckian dual economy model.

It is illusionary to assume that capitalist economies will ever attain full employment under normal situations. ${ }^{3}$ The only period of time in the modern era in which full employment was reached in the United States was during World War II (Kaboub 2007). Kaboub further adds:

Full employment and price stability were achieved, but only during wartime with a considerable number of the male working-age adults being in the army and the rest of the working-age population employed to support the war effort. Therefore, the U.S. full employment experiment must be taken with caution. (Kaboub 2007, 4)

In March 1999, US unemployment reached its lowest since the 1960s and was considered as "full employment." It was then at 4.2 percent, clearly showing that full employment was never reached in the post-war period.

Furthermore, not only is full employment not likely to be achieved, but employment follows business cycles. Indeed, lack of aggregate demand during crisis leads to higher level of unemployment, as Keynes (1936) explained it in his General Theory of Employment, Interest, and Money. All of the components of effective demand are highly sensible to expectations that are depressed during tough times. Therefore, not only is it improbable to attain full employment

\footnotetext{
${ }^{2}$ Kaldor defined underemployment as "analogous to Keynes' definition of 'involuntary unemployment"” (Kaldor 1968, cited in Ros 2000). Ros points out that "the Kaldorian notion of underemployment is also different from [...] the type of unemployment analyzed by modern theories of efficiency wages" (Ros 2000, 96).

${ }^{3}$ Even if full employment was attained due to an important increase in demand, it would be by working at full capacity or over full capacity, and there is a good chance that it would be highly inflationary. As Papadimitriou writes when discussing Keynesian "pump priming" policies: "The problem is that such policies may lead to labor markets tight enough to generate inflation long before 'full' employment is reached" (Papadimitriou 1999, a17).
} 
because of structural unemployment, it is also doubtful that it is maintained due to cyclical unemployment (Forstater 2003).

The policy space for employment policies is thus large and important, and needs commitment.

Unemployment cannot be conquered by a democracy until it is understood. Full productive employment in a free society is possible but it is not possible without taking pains. It cannot be won by waving a financial wand: it is a goal that can be reached only by conscious continuous organization of all our productive resources under democratic control. To win full employment and keep it, we must will the end and must understand and will the means. (Beveridge 1945, as cited in Papadimitriou 1999)

\subsection{Employment Policies}

Full employment was the objective of employment policies in the post World War II period until the mid-1970s. Then, we observed a switch in the goal of employment policies. We went from what Mitchell and Muyskens (2008) call a "full employment framework" to a "full employability framework." "Employment is now seen as a microeconomic problem. Employment policies are not macroeconomic or Keynesian aggregate demand spur anymore. They are now designed as microeconomic and supply-side.

According to the full employability framework, unemployed workers are unemployed because they are not attractive enough and they need to be more "sexy" in order to find a job. Active labor market policies (ALMPs) are examples of these micro policies. The effectiveness of ALMPs is not encouraging according to de Koning (2001) and Martin (1998). However, Martin stresses their potential role in fighting high and persistent unemployment, while de Koning underlines the increasing need for these policies in the future.

On the macroeconomic side, the "fit-all" solution is growth: in order to have more jobs, an economy needs to grow. According to Minsky, focusing on pro-growth rather than employment policies is a mistake, since a fully employed economy is bound to grow while a growing economy might not be at full employment (Minsky 1986). And indeed correlation between employment growth and GDP growth are mixed, as Table 1 shows.

\footnotetext{
${ }^{4}$ Papadimitriou (1999) talks about a change from full employment policies toward maximum employment policies.
} 
Table 1. Correlation between GDP growth and employment growth is varying from not correlated at all (United Kingdom, Turkey) to slightly correlated (Chile, Japan) to strongly correlated (United States).

\begin{tabular}{|l|c|}
\hline & Correlation \\
\hline Australia (1965-2010) & 0,16 \\
Chile (1987-2010) & 0,48 \\
Germany (1970-2010) & 0,14 \\
Italy (1970-2010) & 0,20 \\
Japan (1970-2010) & 0,60 \\
Turkey (1970-2010) & 0,10 \\
United Kingdom (1970-2010) & 0,05 \\
United States (1970-2010) & 0,77 \\
\hline
\end{tabular}

Source: OECD 2011

What emerges from present analysis of the effectiveness of employment policies is that, even if some have interesting results, none of them has achieved the low unemployment level of the post-WWII period. Furthermore, these policies do not aim at full employment anymore, but at maximum employment possible under present conditions. We need a change in employment policies such that full employment again becomes the target of these policies.

\subsection{A Role for the Government}

Market economy only chooses to produce what has a price and what is profitable to the producer. As Lunghini (1995) puts it, "production of goods stops not when needs are satisfied but when profit realization imposes it" (my translation). Thus, a good without a price would not be produced since no monetary profits can be extracted from it. What is more, some needs will never be satisfied by an economy that is only interested in what is profitable. Entire sectors of the economy would not exist if not for government programs and policies.

Also, governments might have a better vision of the best direction for the economy for the benefit of all. Climate change is a good example of such cases. We thus need a government that is able to both influence the structure of the economy and drive it to what would be more profitable for all ${ }^{5}$ (Forstater 1998; Mitchell 2007).

Besides, Forstater (1998) notes that increased private sector activity can lead to bottlenecks or inflationary pressure due to utilization of excess capacities or resource depletion. Indeed, because of structural rigidities of the economy or competitive pressures, private sector firms may choose not to change technology or to engage in natural resource-intensive means of

\footnotetext{
${ }^{5}$ Not that the private sector is incapable of introducing technical change benefitting everyone, but in some cases, the cost of introducing those changes might be a barrier to these investments, even if in the long run it would be profitable.
} 
production without observing the negative externalities it would imply. Governments, free of these rigidities or pressures, are more able to conduct structural changes. According to Lerner (1951), we cannot trust the people to drive the economy correctly because, even if they know the consequences of their acts, they will misbehave if it is in their own interest. Consequently, there is a need for the state to take over the steering wheel of the economy. For example, "investments can be undertaken by the governments which shows a money loss but which are considered worth while in the social interest because they yield benefits other than those which result in a money income" (Lerner 1951, 91). Finally, Keynes stresses the importance of public investments, pointing out "that a somewhat comprehensive socialization of investment will prove the only means of securing an approximation to full employment” (Keynes 1936, 378).

\section{A MULTI-SECTORIAL SFC MODEL}

\subsection{Stock-Flow Consistency in a Nutshell}

The stock-flow consistent (SFC) approach is a very active strand of the Post-Keynesian literature. As SFC models are nominal models, they are well-fitted to analyze the financial-real interactions. Some authors work on growth and distribution models, such as Lavoie and Godley (2001-2002), Dos Santos and Zezza (2004, 2006, 2008), Dos Santos and Macedo e Silva (2009), and Foley and Taylor (2006) among others. SFC models may also be used to analyze investment decisions, such as in Chatelain (2010). Others use agent-based SFC models (see Kinsella et al. 2011; Seppecher 2010). Finally, Bellofiore and Passarella (2010) and Passarella (2010) among others use Minskyan SFC models to analyze financial instability.

The economy presented here is composed of two household sectors (wage earners and capitalists), three production industries (energy, investment, and widget), and one public sector. Intermediate goods are not shown in each of the industries. However, some goods produced in one industry serve as inputs for other industries. ${ }^{6}$

Only three industries are modeled. Godley and Lavoie (2007), often have only one production sector justify this assumption for the sake of simplicity. Lee (1998) criticizes this choice, pointing out the lack of pricing interdependencies. This critique does not apply to our model since we will be able to observe some pricing interdependence as the three productive sectors are using output of other industries as input for their own production.

\footnotetext{
${ }^{6}$ Sectors in this economy are thus not vertically integrated as Pasinetti (1981) defines it.
} 


\subsection{Structure of the Model}

Table 2 is the social account matrix (SAM) of the economy. ${ }^{7}$ It shows how flows circulate in the economy. The SAM allows us to see what the earnings (row) and spending (column) of each sector are. For example, the first row shows that earnings from the energy sector is composed of consumption from the widget sector $\left(C_{w, e}\right)$ and the capital sector $\left(C_{i, e}\right)$, from both household sectors $\left(C_{h, e}\right.$ and $\left.C_{c a, e}\right)$ and from the public sector $\left(C_{g, e}\right)$, while the first column reveals that the energy sector spends all its income in investments $\left(I_{e}\right)$, wages $\left(N_{e} W_{e}\right)$, profits $\left(F_{e}\right)$, and interests $\left(r_{l} L_{e,-1}\right)$.

Table 2. Social Account Matrix

\begin{tabular}{|c|c|c|c|c|c|c|c|c|}
\hline & Energy & Widget & Cap. Goods & Wage earners & Capitalists & Government & Banks & Total \\
\hline Energy & & $C_{w, e}$ & $C_{i, e}$ & $C_{h, e}$ & $C_{c a, e}$ & $C_{g, e}$ & $+\Delta L_{e}$ & $Y_{e}$ \\
\hline Widget & & & & $C_{h, w}$ & $C_{c a, w}$ & $C_{g, w}$ & $+\Delta L_{w}$ & $Y_{w}$ \\
\hline Capital Goods & $I_{e}$ & $I_{w}$ & $I_{i}$ & & & & $+\Delta L_{i}$ & $Y_{i}$ \\
\hline Wage earners & $N_{e} W_{e}$ & $N_{w} W_{w}$ & $N_{i} W_{i}$ & & & $G_{T} U+r_{b} B_{h,-1}$ & & $Y_{h}$ \\
\hline Capitalists & $F_{e}$ & $F_{w}$ & $F_{i}$ & & & $r_{b} B_{c a,-1}$ & $F_{b}$ & $Y_{c a}$ \\
\hline Government & & & & $T_{h}+\Delta B_{h}$ & $T_{c a}+\Delta B_{c a}$ & & $\Delta B_{b}$ & $T+\Delta B$ \\
\hline Banks & $r_{l} L_{e,-1}$ & $r_{l} L_{w,-1}$ & $r_{l} L_{i,-1}$ & $+\Delta M_{h}$ & $+\Delta M_{c a}$ & $r_{b} B_{b,-1}$ & & $Y_{b}$ \\
\hline Total & $Y_{e}$ & $Y_{w}$ & $Y_{i}$ & $Y_{h}$ & $Y_{c a}$ & $G$ & $Y_{b}$ & \\
\hline
\end{tabular}

Table 3 is the balance sheet. It represents how stocks are distributed among the different sectors. It shows that net worth of firms is equal to zero, as all their wealth is transferred to capitalists. It also indicates that banks have no net worth, as they use bond holding to balance their liabilities and assets. Private wealth is thus composed of financial wealth (cash and bonds) from households and real wealth (firms' net worth) from capitalists' households. Financial private net worth is balanced by public net worth as shown by the Balance row of the balance sheet.

Table 3. Balance Sheet

\begin{tabular}{|r|ccccccc|l|}
\hline & Energy & Widget & Capital goods & Wage earners & Capitalists & Government & Banks & $\Sigma$ \\
\hline Fixed Capital & $+K_{e}$ & $+K_{w}$ & $+K_{i}$ & & & & & $+K$ \\
Cash & & & & $+M_{h}$ & $+M_{c a}$ & & $-M$ \\
Bonds & & & & $+B_{h}$ & $+B_{c a}$ & $-B$ & $+B_{b}$ & 0 \\
Loans & $-L_{e}$ & $-L_{w}$ & $-L_{i}$ & & & $+L$ & 0 \\
Owned Firms & $-V K_{e}$ & $-V K_{w}$ & $-V K_{i}$ & & $+V K$ & & & 0 \\
\hline Balance & 0 & 0 & 0 & $-V_{h}$ & $-V_{c a}$ & $+V_{g}$ & 0 & $-V$ \\
\hline$\Sigma$ & 0 & 0 & 0 & 0 & 0 & 0 & 0 & 0 \\
\hline
\end{tabular}

\footnotetext{
${ }^{7}$ For a complete list of the variables, see appendix A.
} 
The transaction flow matrix (TFM), table 4, ensures that the sum of all flows is always nil. A plus sign expresses an inflow, while a minus sign represents an outflow. For instance, the third row shows that wages are paid by the three productive sectors to wage earners, and thus come with a minus sign in the Energy column and with a plus sign in the Wage earners sector. From tables 2 and 4, we can see that profits are distributed to the capitalist class. Household sectors consume both energy and widgets, pay taxes $\left(T_{h}\right.$ and $\left.T_{c a}\right)$, and save everything left either as bonds $\left(\Delta B_{h}\right.$ and $\left.\Delta B_{c a}\right)$ or as cash $\left(\Delta M_{h}\right.$ and $\left.\Delta M_{c a}\right)$. Banks hold deposits from both kinds of households, receive interests for the loans accorded to firms and from the bonds they hold. Finally, government, seen here as both the government and the central bank, consumes both energy and widgets, transfers unemployment benefits $\left(G_{T}\right)$ to jobless wage earners, and pays interests to bonds holders. The change in stock is represented in the second part of the TFM.

Table 4. Transaction Flow Matrix

\begin{tabular}{|c|c|c|c|c|c|c|c|c|c|c|c|c|}
\hline & \multicolumn{2}{|c|}{ Energy } & \multicolumn{2}{|c|}{ Widget } & \multicolumn{2}{|c|}{ Investment } & \multirow[t]{2}{*}{ Wage Earners } & \multirow[t]{2}{*}{ Capitalists } & \multirow[t]{2}{*}{ Government } & \multicolumn{2}{|c|}{ Bank } & \multirow[t]{2}{*}{$\Sigma$} \\
\hline & Current & Capital & Current & Capital & Current & Capital & & & & Current & Capital & \\
\hline Consumption & & & $+C_{w}$ & & & & $-C_{h, w}$ & $-C_{c a, w}$ & $-C_{g, w}$ & & & 0 \\
\hline Energy & $+C_{e}$ & & $-C_{w, e}$ & & $-C_{i, e}$ & & $-C_{h, e}$ & $-C_{c a, e}$ & $-C_{g, e}$ & & & 0 \\
\hline Investments & & $-I_{e}$ & & $-I_{w}$ & $+I$ & $-I_{i}$ & & & & & & 0 \\
\hline Wages & $-W_{e} N_{e}$ & & $-W_{w} N_{w}$ & & $-W_{i} N_{i}$ & & $+W B$ & & & & & 0 \\
\hline $\begin{array}{l}\text { Retained } \\
\text { Earnings }\end{array}$ & $-R E_{e}$ & $+R E_{e}$ & $-R E_{w}$ & $+R E_{w}$ & $-R E_{i}$ & $+R E_{i}$ & & & & & & 0 \\
\hline Profits & $-F_{e}$ & & $-F_{w}$ & & $-F_{i}$ & & & $+F$ & & $-F_{b}$ & & 0 \\
\hline $\begin{array}{l}\text { Loan Inter- } \\
\text { est }\end{array}$ & $-r_{l} L_{e,-1}$ & & $-r_{l} L_{w,-1}$ & & $-r_{l} L_{i,-1}$ & & & & & $+r_{l} L_{-1}$ & & 0 \\
\hline $\begin{array}{l}\text { Bond Inter- } \\
\text { ests }\end{array}$ & & & & & & & $+r_{b} B_{h,-1}$ & $+r_{b} B_{c a,-1}$ & $-r_{b} B_{-1}$ & $+r_{b} B_{b,-1}$ & & 0 \\
\hline Transfers & & & & & & & $+G_{T} U$ & & $-G_{T} U$ & & & 0 \\
\hline Taxes & & & & & & & $-T_{h}$ & $-T_{c a}$ & $+T$ & & & 0 \\
\hline $\begin{array}{l}\text { Change in } \\
\text { loans }\end{array}$ & & $+\Delta L_{e}$ & & $+\Delta L_{w}$ & & $+\Delta L_{i}$ & & & & & $-\Delta L$ & 0 \\
\hline $\begin{array}{l}\text { Change in } \\
\text { deposits }\end{array}$ & & & & & & & $-\Delta M_{h}$ & $-\Delta M_{c a}$ & & & $+\Delta M$ & 0 \\
\hline $\begin{array}{l}\text { Change in } \\
\text { bonds }\end{array}$ & & & & & & & $-\Delta B_{h}$ & $-\Delta B_{c a}$ & $+\Delta B$ & & $-\Delta B_{b}$ & 0 \\
\hline $\begin{array}{l}\text { Change in } \\
\text { net worth }\end{array}$ & & $+\Delta V K_{e}$ & & $+\Delta V K_{w}$ & & $+\Delta V K_{i}$ & & $-\Delta V K$ & & & & 0 \\
\hline$\Sigma$ & 0 & 0 & 0 & 0 & 0 & 0 & 0 & 0 & 0 & 0 & 0 & 0 \\
\hline
\end{tabular}

The following subsections describe the model; a complete list of all the equations of the model can be found in appendix B.

\subsection{Household Sectors}

\subsubsection{Wage Earners}

Wage earners offer their labor for a salary and receive a dole when unemployed. Furthermore, they perceive interests for their bond holding. Their aggregated nominal disposable income is thus composed of the wage bill minus taxes, of the unemployment benefits, and of interests on 
bonds. We assume nominal wages and unemployment benefits are fixed, as we are not interested in inflation processes.

We suppose that wage earners construct a consumer price index (CPI) and an inflation rate based on their preferences and on prices of energy and widgets. We then define a real disposable income based on Haig-Simons' definition ${ }^{8}$ in order to determine their consumption level. Total real consumption is a function of Haig-Simons' real disposable income and real wealth in previous periods. Wage earners' consumption of energy and widgets is determined through a linear expenditure system (LES), reflecting their preferences over energy and widgets, and according to relative prices and minimum consumption of both goods.

All disposable income that is not consumed is saved. Wage earners face a portfolio decision, as they have to choose to hold their wealth as bonds or as cash. They choose their desired holding of bonds based on previous stock of wealth and interest rate on bonds. Cash holding is then equal to residual wealth (i.e., nominal wealth minus bond holding).

\subsubsection{Capitalists}

Capitalists' aggregate disposable income is composed of profits from all productive sectors and banks, minus taxes plus interests from bonds. As wage earners, capitalists consume both energy and widgets and save all income that is not spent as cash. Wealth of capitalists consists of their financial wealth (cash and bonds) and of firms' net wealth since capitalists own them. As a consequence, firms' wealth will affect the consumption decision of capitalists. ${ }^{9}$ Portfolio choice for capitalists is based on financial wealth only, and not on total wealth.

\footnotetext{
${ }^{8}$ Haig (1921) and Simons (1938) define income as the sum of consumption and variation in wealth. According to Godley and Lavoie (2007, 293-294), Haig-Simons' real disposable income is composed of real disposable income minus the loss of real wealth due to inflation.

${ }^{9}$ This has strong implications. As we will see later, firms' net wealth is positive and potentially large. This implies that, depending on the propensity to consume out of wealth, there might be some cases where consumption is larger than income. At some point, financial wealth might be negative. This means that capitalists borrow to consume, using their share as collateral. The value of that parameter is thus crucial (Taylor 2008). Let's assume, for example, that $I>S$ because investments have increased. Since $I$ is larger than before, income increases, and thus savings increases, too. This increase in savings implies then an increase in consumption out of wealth and thus also an increase in investments. This either stabilizes towards $I=S$ or might explode into an unstable situation. The propensity to consume out of wealth affects the accelerator.
} 


\subsection{Production Sectors}

\subsubsection{Demand}

All production sectors are demand-driven. They all need fixed capital stock in order to produce. Because we assume integrated sectors, there are no intermediate goods and each output is net output. However, all productive sectors need electricity in order to produce their respective goods. Sectorial demands in electricity are determined through energy productivity in each industry. The energy sector has a demand equal to household consumption plus demand from the two other productive sectors and from the public sector. Aggregate demand for widgets is equal to households' and government's desired consumption. Demand in the capital good industry is composed of investment from the three productive sectors. Capital stock level determines maximum output to be produced in each period.

\subsubsection{Employment}

Employment in each sector is demand-determined through sectorial productivity. Firms assume as many workers as they need to produce enough goods to satisfy the demand they face. We assume perfect mobility of labor and no differentiation of workers. Firms hire workers from the labor force up to the level of employment they need. Unemployment is equal to the difference between labor force and aggregate employment.

\subsubsection{Investments}

Desired capital growth $\left(g_{k}, 1\right)$ is a function of actual capacity utilization ${ }^{10}(u)$ and targeted capacity utilization $\left(u^{T}\right)^{11}$. Capacity utilization (2) is defined as the ration of actual output $(y)$ and practical ${ }^{12}$ full capacity output $\left(y_{f c}\right)$, which is computed through (3), where $p r_{k}$ is capital productivity under normal conditions. Real investment is equal to desired capital growth plus depreciation rate, but cannot be negative (4).

$$
g_{k}=\gamma_{0}+\gamma_{1}\left(u_{-1}-u^{T}\right)
$$

\footnotetext{
${ }^{10}$ In this paper, we follow Robinson (1969) in that firms might make mistakes in their estimation of output growth, creating unwanted excess capacity, and Lavoie (1992), as firms also plan some excess capacity in order to avoid constraining demand in case of a large growth in demand.

${ }^{11}$ We use here a simplified version of Fazzari and Mott (1986) and Lavoie and Godley (2001-2002), since we assume that firms have fixed targeted leverage level and return rates. The effect of these normally non-fixed variables is thus contained in $\gamma_{0}$. The formulation of the investment function is similar to (Lavoie et al. 2004).

${ }^{12}$ Practical or engineer-rated full capacity is the maximum level of production such that it allows normal maintenance and renovation of machinery to take place without impeding production (Eichner 1976; Steindl 1952).
} 


$$
\begin{aligned}
& u=\frac{y}{y_{f c}} \\
& y_{f c}=k \cdot p r_{k} \\
& i=\operatorname{Max}\left[g_{k}+\delta, 0\right] k_{-1} \\
& \Delta k=i-\delta . k_{-1}
\end{aligned}
$$

\subsubsection{Costs}

Unit costs are a decreasing linear function of output ( $y$ ), for a given stock of capital $(k)$ and a given stock of debt $(L),{ }^{13}$ up to the level of practical full capacity. After that point, unit costs are a quadratic increasing function of output until technical full capacity (Lavoie 1992). ${ }^{14}$

$$
U C(y)=\left\{\begin{array}{lll}
\frac{W}{p r_{n}}+\frac{\delta \cdot k+r_{l} L_{-1}}{y} & \text { if } & u \leq 1 \\
\beta+\alpha\left(y-y_{f c}\right)^{2} & \text { if } & u>1
\end{array}\right.
$$

where $\frac{W}{p r_{n}}$ are the labor unit costs. From (1) and (4), we observe that when $u<u^{T}-\frac{\delta+\gamma_{0}}{\gamma_{1}}=u_{\text {min }}$ firms are not replacing depreciated capital. The unit cost function is thus modified in order to reflect this choice:

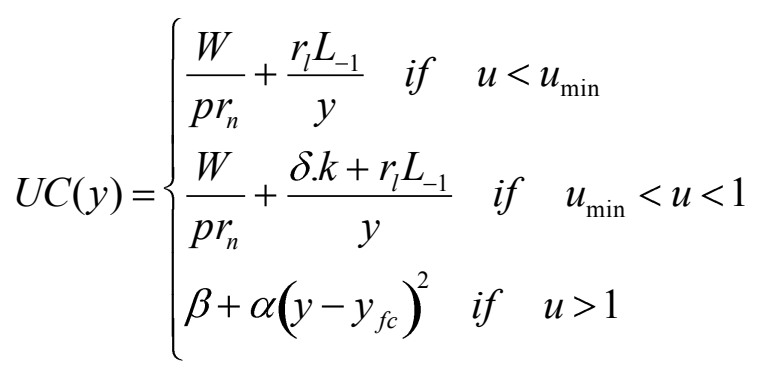

\subsubsection{Prices}

Prices are Kaleckian markup prices based on unit cost. ${ }^{15}$ The markup is used to generate profits, which are then divided in two. The first part of profits is distributed to shareholders as dividends; the second part is used to finance investments or to repay loans. For explicative

\footnotetext{
${ }^{13}$ We include capital replacement and debt servicing in the unit costs without loss of generality. The other solution would be to exclude both of these costs from unit costs and to change the dividend-related part of markup so that that part of profits can also service the debt on top of paying dividend to shareholders. Both solutions are valid. The present choice simplifies markup computation, but does not allow computing easily the wage share.

${ }^{14}$ Such a function of piecewise unit costs is based on constant marginal costs up to practical full capacity. When maintenance cannot be performed and when workers work overtime, marginal costs increase drastically, implying the increasing quadratic unit costs function.

${ }^{15}$ For more information on Post-Keynesian pricing theory, see Lee (1998).
} 
purposes, the markup is thus divided in two: $\tau=\theta+\phi . \theta$ is the part of the markup related to dividends, while $\phi$ is the part of market related to investments.

$$
p=(1+\theta+\phi) U C\left(y^{e}\right)
$$

Dividends are assumed to be targeted such that they are equal to the desired return on capital $r_{s}$ times the capital stock (9), based on expected sales $y^{e}$ and expected unit costs $U C\left(y^{e}\right)$ (10).

$$
\begin{array}{r}
F=r_{s} p_{k,-1} k_{-1} \\
\theta=\frac{r_{s} p_{k,-1} k_{-1}}{U C\left(y^{e}\right) y^{e}}
\end{array}
$$

Kalecki (1971) shows that a fraction $\rho$ of retained earnings $(R E)$ can be borrowed to finance investments. When firms decide to invest, they need to generate sufficient retained earnings in order to finance their desired level of investments. Furthermore, we assume that firms are targeting a fixed level of leverage ( $\left.\lambda^{T}\right)$. Given the level of investment (4), the actual level of leverage $(\lambda, 11)$ and targeted level of leverage, firms decide what fraction of nominal investment is to be borrowed (12). In the case where it is not possible to reach the targeted level of leverage given desired investment (and thus $\rho$ should be negative), we assume that firms use retained earnings not only to finance investment, but also to repay loans. Targeted retained earnings being determined by (13), the markup $\phi$ is determined through (14).

$$
\begin{aligned}
& \lambda=\frac{L}{p_{k} k} \\
& \rho=\frac{L}{p_{k} k} \\
& R E^{e}=\phi U C\left(y^{e}\right) y^{e} \\
& \phi=\frac{g_{k} k \cdot p_{k}}{(1+\rho) U C\left(y^{e}\right) y^{e}}+z \frac{L-\lambda^{T} p_{k} k+i}{U C\left(y^{e}\right) y^{e}} \\
& z=1 \quad \text { if } \quad \rho=0
\end{aligned}
$$

Expected sales growth is inversely proportional to price inflation (16).

$$
y^{e}=y_{-1}(1-\hat{p})
$$

The pricing decision that firms face may be summarized by figures 2 and 3 . The blue line represents expected sales as a function of price. The purple line represents needed sales for a given price so that the firm is able to finance investment and debt repayment. The intersections 
of the two lines are possible prices such that retained earnings are equal to their desired level. If the level of desired retained earning is low enough (case a), then there are one or two possible prices, one that maximizes output and one that maximizes prices. We assume that firms always choose the output maximizing solution. However, there are cases where, given the desired level of retained earnings, there is no solution to the system (case b). Firms then have to lower their desired level of retained earnings.

Figure 2. Case a - two possible prices

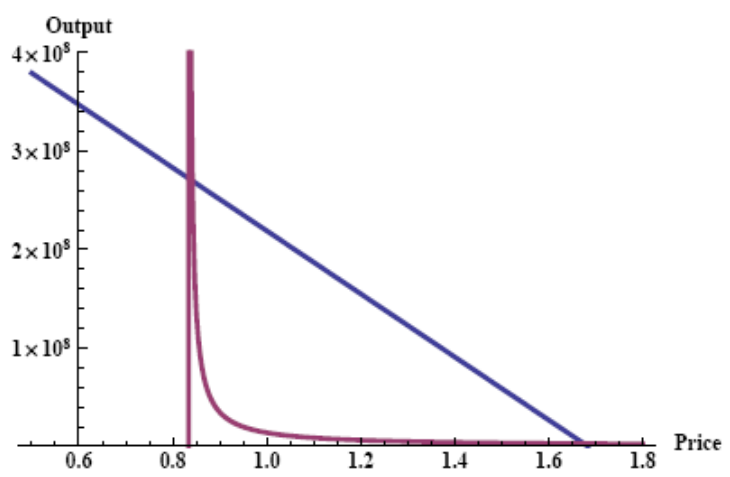

Figure 3. Case $\mathrm{b}-$ no possible price

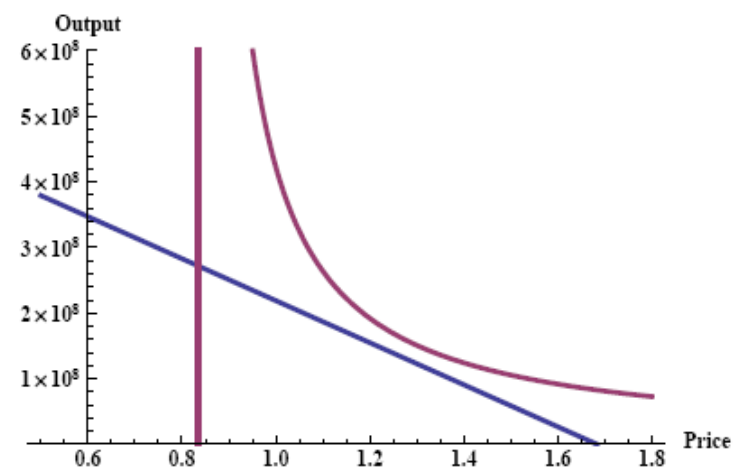

Note: Firms' pricing decision. The blue line represents expected sales as a function of price. The purple line represents desired sales for a given price in order to be able to finance investment and debt repayment. The intersections of the two lines are possible prices such that retained earnings meet their desired level.

\subsubsection{Finance}

Variation in loans (18) is equal to nominal investments minus realized retained earnings (17).

Net wealth of firms is equal to tangible assets minus liabilities (19).

$$
\begin{aligned}
& R E=(p-U C(y)) y-F \\
& \Delta L=p_{k} i-R E \\
& V=p_{k} k-L
\end{aligned}
$$

\subsection{Banking Sector}

Banks are not supposed to hold any cash reserves; the stock of deposits is equal to the stock of

loans to firms plus the stock of government bonds. We assume that banks respond positively to all loans demands and that loans are always repaid. Bond holding is then a residual choice.

Profits are made of interests from loans and bonds.

\subsection{Government Sector}

Public sector income is given by tax receipt while expenditures are composed of energy consumption, widget consumption and unemployment subsidies. We assume, at first and with 
no loss of generality, fixed total nominal public consumption of energy and widgets.

Households and banks determine bond demand while bond supply is equal to the budget deficit.

\section{STEADY STATE}

As the model is static, a steady state is reached when variations in stocks are all nil. For the capital stock to be constant, growth in capital has to be nil, in which case investments are equal to capital depreciation. Furthermore, leverage level has to have reached its targeted value. Hence when capacity utilization and leverage level have reached their steady state value, a system of equations depending on various parameters and the level of capacity utilization determines prices. ${ }^{16}$

In order to find steady state levels of capital stock, wealth, disposable income, etc. other observations are needed. At the steady state, household wealth is constant. Besides, inflation is nil. All income is spent and income is equal to a fraction of wealth. Bond and cash holdings also are constant. This determines a second system of equations.

From these two systems of equations, it is interesting to note that prices depend only on targeted values of capacity utilizations and leverage levels, and on technical and financial parameters such as productivity, depreciation, interest, and return rates. Furthermore, the role of a few essential parameters may be observed. These parameters represent key behavioral elements. Influencing those behaviors could impact aggregate indicators such as employment, income, or poverty. This underlines the multiplicity of means in order to attain certain goals.

First of all, the leverage level $(\lambda)$ and the capacity utilization rate $(u)$ have a redistributive effect between capitalists and wage earners, as figures 4 and 5 show. The leverage level ( $\lambda$ ) has a positive impact on capitalists' income. Furthermore, a decrease in capacity utilization also increases capitalists' income through an increase in capital stock, and thus on return on capital for the same output. Both these parameters have only a small direct impact on wage earners' income. What is more, both these parameters have a positive impact on prices, and thus reduce real wages of workers. On the aggregate, the leverage level and the capacity utilization have a light impact on employment (higher leverage and lower capacity imply respectively higher unemployment) and on debt to GDP ratio (higher leverage and higher capacity imply respectively higher debt to GDP ratio).

\footnotetext{
${ }^{16}$ Appendix $\mathrm{C}$ contains the steady state system of equations and the description of the steps to obtain the system.
} 
Figure 4. Real income - wage earners

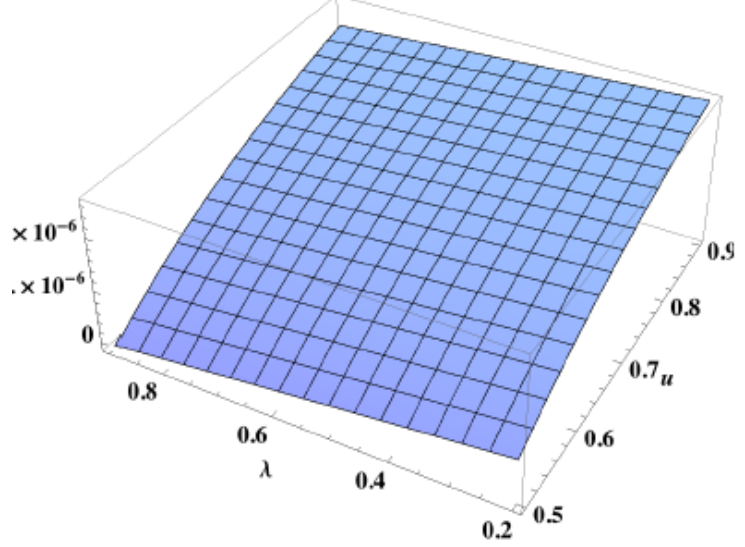

Figure 5: Real income - capitalists

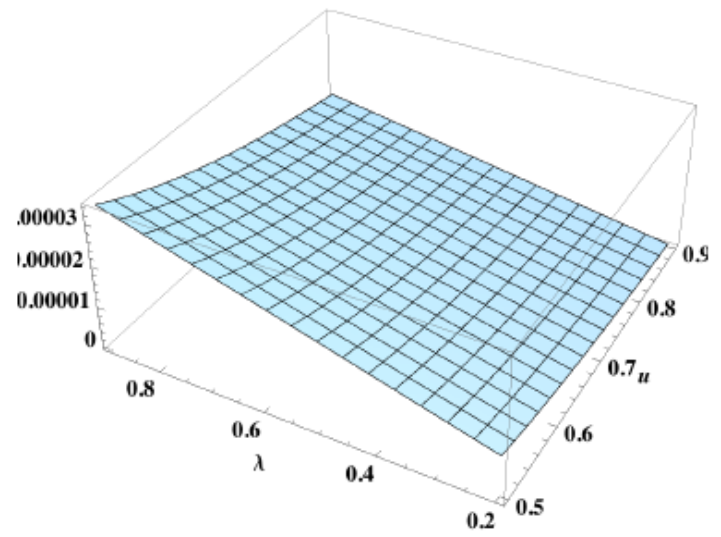

Note:

The redistributive effect of leverage level $(\lambda)$ and capacity utilization $(u)$. Increased leverage increases capitalists' income and decreases wage earners' income. Lower capacity utilization increases capitalists' income and decreases wage earners' income.

The second interesting pair of parameters to analyze is composed of the interest rate on bond holding $\left(r_{b}\right)$ and the level of government consumption $\left(C G=C_{g, e}+C_{g, i}\right)$. Figures 6 and 7 illustrate the impacts that these parameters have on unemployment and debt to GDP ratio. The interest rate on bonds has an obvious income effect for all households, but also has an impact on the quantity of bonds held, which increases income even more. This increased bond holding level has a direct effect on debt to GDP ratio since the debt level is equal to bond supply. Due to the income increase that the interest rate on bonds has, consumption increases with $r_{b}$, implying a reduction in unemployment. Government consumption has a mildly negative effect on debt to GDP ratio. It is negative since the Keynesian multiplier on government spending is higher than one. The level of steady state debt slightly depends on government spending, since debt depends on desired bonds holding by households and banks. Because an increased level of government consumption implies an increase in income for all household sectors, it also implies a higher level of wealth and thus a higher level of bond holding. On the other hand, government spending has a strong impact on unemployment. This is the standard Keynesian demand spur that will be analyzed more in depth in section 5.3. 
Figure 6. Debt to GDP ratio

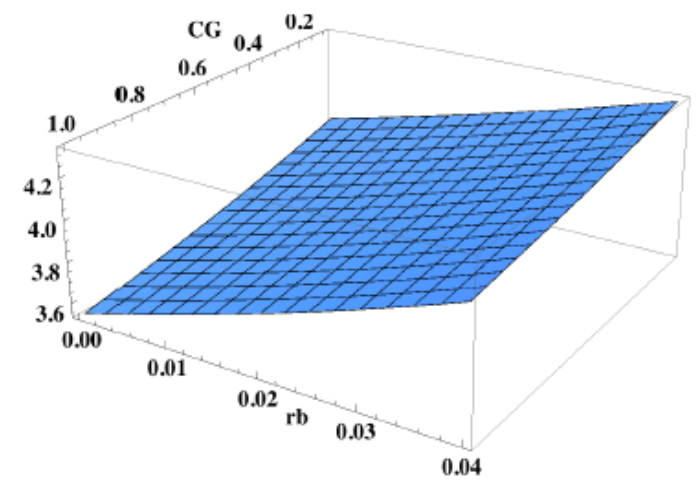

Figure 7. Unemployment

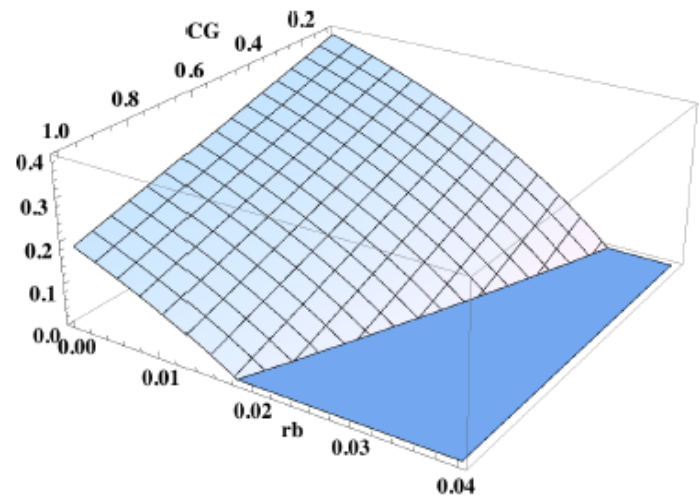

Effects of government consumption (CG) and interest on bonds (rb) on debt to GDP ratio and unemployment. While the interest rate has a strong impact on both debt to GDP ratio and unemployment, public consumption surprisingly has little effect on public debt. However, public spending strongly impacts unemployment through a demand spur.

\section{GREEN JOBS}

Literature on cost-benefit analysis of green buildings is wide. Some authors focus only on domestic houses (Clinch and Healy 2001, Hens and Verdonck 2001, Levine et al. 2007, POST 2005), while others focus on public buildings (Kats et al. 2005, Kats 2006, Lee et al. 2000). Generally, various benefits are cited: energy and water savings, improved health and decreased mortality, enhanced student learning, increased productivity, job creation - all leading to clear economic and social profits. ${ }^{17}$ We will only consider energy savings both in dwellings and public buildings.

\subsection{Adding the ELR into the Model}

Introducing a green-job employer-of-last-resort (ELR) into the economy does not change the model much. Table 5 is the social account matrix. The only difference from the previous model is that now unemployed workers do not receive an unemployment subsidy, but are employed by the state for a minimum wage. The balance sheet does not change and is not reproduced here.

\footnotetext{
${ }^{17}$ Kats (2006) computes a net financial benefit of USD 71 per feet of Green School built.
} 
Table 5. Social Account Matrix

\begin{tabular}{|c|c|c|c|c|c|c|c|c|}
\hline & Energy & Widget & Cap. Goods & Wage earners & Capitalists & Government & Banks & Total \\
\hline Energy & & $C_{w, e}$ & $C_{i, e}$ & $C_{h, e}$ & $C_{c a, e}$ & $C_{g, e}$ & $+\Delta L_{e}$ & $Y_{e}$ \\
\hline Widget & & & & $C_{h, w}$ & $C_{c a, w}$ & $C_{g, w}$ & $+\Delta L_{w}$ & $Y_{w}$ \\
\hline Capital Goods & $I_{e}$ & $I_{w}$ & $I_{i}$ & & & & $+\Delta L_{i}$ & $Y_{i}$ \\
\hline Wage earners & $N_{e} W_{e}$ & $N_{w} W_{w}$ & $N_{i} W_{i}$ & & & $U W_{E L R}+r_{b} B_{h,-1}$ & & $Y_{h}$ \\
\hline Capitalists & $F_{e}$ & $F_{w}$ & $F_{i}$ & & & $r_{b} B_{c a,-1}$ & $F_{b}$ & $Y_{c a}$ \\
\hline Government & & & & $T_{h}+\Delta B_{h}$ & $T_{c a}+\Delta B_{c a}$ & & $\Delta B_{b}$ & $T+\Delta B$ \\
\hline Banks & $r_{l} L_{e,-1}$ & $r_{l} L_{w,-1}$ & $r_{l} L_{i,-1}$ & $+\Delta M_{h}$ & $+\Delta M_{c a}$ & $r_{b} B_{b,-1}$ & & $Y_{b}$ \\
\hline Total & $Y_{e}$ & $Y_{w}$ & $Y_{i}$ & $Y_{h}$ & $Y_{c a}$ & $G$ & $Y_{b}$ & \\
\hline
\end{tabular}

\subsubsection{Equations Modifications}

There are no substantial modifications. First of all, as already stated, wage earners' income is now composed of private sector earnings and ELR wage instead of the dole. Second, works done under ELR have an effect both on governmental and household energy consumption. Equation (20) shows that we relax the hypothesis of constant government spending, as public energy consumption decreases proportionally to the size of ELR (measured by $u$, the private unemployment rate). Equation (21) indicates that wage earners' propensity to consume energy ( $\beta_{h}$ ) also diminishes proportionally to the ELR size.

$$
\begin{aligned}
& C_{g, e}=\left(1-\xi_{g} u\right) C_{g, e,-1} \\
& \beta_{h}=\left(1-\xi_{h} u\right) \beta_{h,-1}
\end{aligned}
$$

\subsection{Green-Job ELR vs. Baseline}

The first set of simulations ${ }^{18}$ analyses the structural effect on the economy of a green-job ELR scheme (hereafter GJ). The GJ starts in period 25. The policy consists of an expected increase of total government spending of 10 percent, an increase that is devoted to the wage paid to ELR workers. ${ }^{19}$ Furthermore, ELR changes the consumption patterns of both wage earners and the public sector following (20) and (21). It is important to note that since these two equations constantly modify the parameters, no steady state can be reached. The economy is constantly changing according to the new preferences of wage earners as well as to the new government spending.

\footnotetext{
${ }^{18}$ The simulations were conducted using Mathematica. The code may be found on the website http://sfcmodels.net/.

${ }^{19}$ Privately unemployed workers thus receive $\$ 11,882$ as unemployment subsidy before ELR is enacted and receive $\$ 19,991$ as ELR wage after.
} 
Figures $8,9,10,11,12$, and 14 show the results obtained through these simulations. In all graphs, the blue line represents the green-job ELR results, while the red line represents the baseline ones. All the results are relative changes from steady state values.

Obviously, unemployment disappears as soon as ELR is put into action. However, not all workers are employed in the private sector. The analysis is conducted on how private unemployment (i.e., all workers not employed in the private sector; that is, ELR workers) varies. Figure 8 shows that private unemployment decreases directly by almost 15 percent. Then, due to the structural change that green jobs imply, private unemployment keeps decreasing rather steeply, at first, then more gently. This result of decreasing unemployment depends on whether the energy sector is more or less labor intensive than the consumption good industry. It is also interesting to note that the predicted 10 percent increase in government spending is not reached at all. Private unemployment decreases drastically due to the increase in aggregate consumption from both household sectors, lowering the cost of ELR.

Both households sectors see an increase in their income after the green-job program is enacted. This leads to an increase in their wealth, resulting in an increase in desired bond holding. This implies an increase in the public debt level. Furthermore, GDP increases also, due to an increase in consumption and investments. The increase in public debt is nonetheless larger than the increase in GDP, leading to an increased level of debt to GDP of about 0.4 percent. The 6 percent increase in government expenditure observed at the beginning of the program is lowered as private unemployment keeps decreasing, removing workers out of ELR and as public energy consumption decreases.

The structural change in the economy can be observed through employment in widget and energy production sectors. In the short run, the increase in income by both wage earners and capitalists increases energy consumption. In the long run, the reduction in energy consumption by both the public sector and wage earners leads to a reduction in energy consumption. This leads to a reduction in employment in the energy industry. However, the reduction in energy employment is countered by an increase in the widget sector. ${ }^{20}$

Three conclusions can be drawn from this analysis. First, an ELR is a direct way to remove all involuntary unemployment and address poverty issues. Second, a green-job ELR implies structural changes in the economy, aiming at lower energy consumption. Regarding the

\footnotetext{
${ }^{20}$ As noted before, the total reduction or increase in employment depends on whether the energy industry is more or less labor intensive than the widget one.
} 
structural change, the present model does not include synergy effects that a green-job public sector might imply. It is obvious that imitative firms would appear on the market as soon as new green technologies would be used in the green-job program. Finally, aggregate ELR cost has to be lowered by the reduction in unemployment due to the spur in aggregate demand that higher income implies. In our simulation, a predicted 10 percent increase in government spending leads to an ex-post increase of only 4 percent. Furthermore, poor people usually receive benefits, which could be removed for ELR workers, further lowering the cost of ELR.

Figure 8. Private unemployment

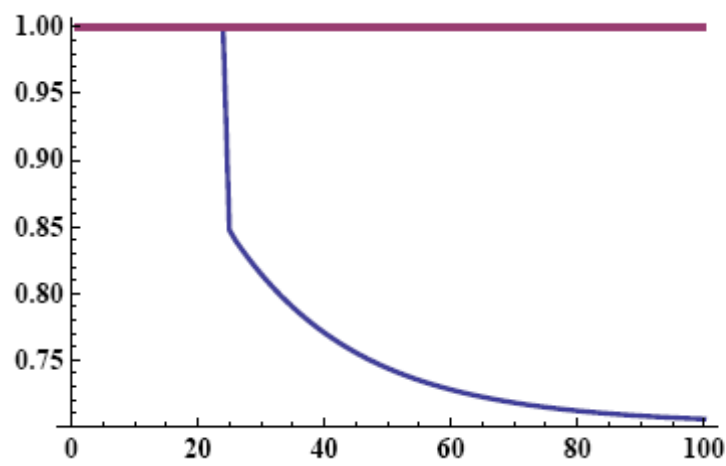

Figure 10. Debt to GDP

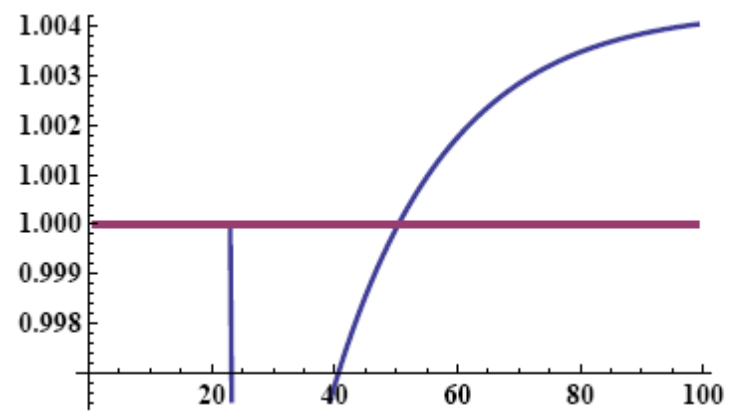

Figure 12. Income

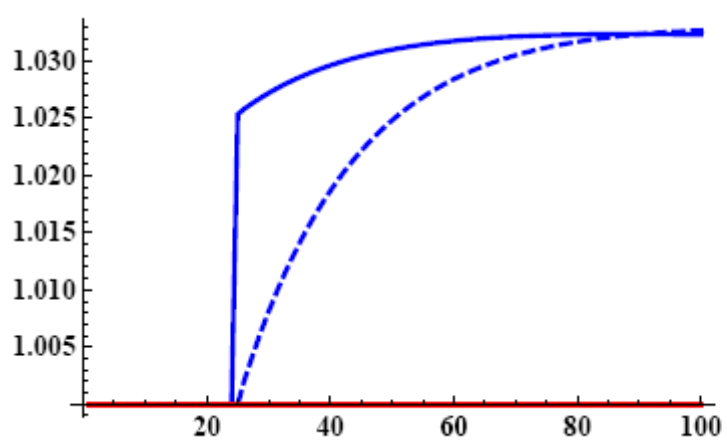

Figure 9. Government budget

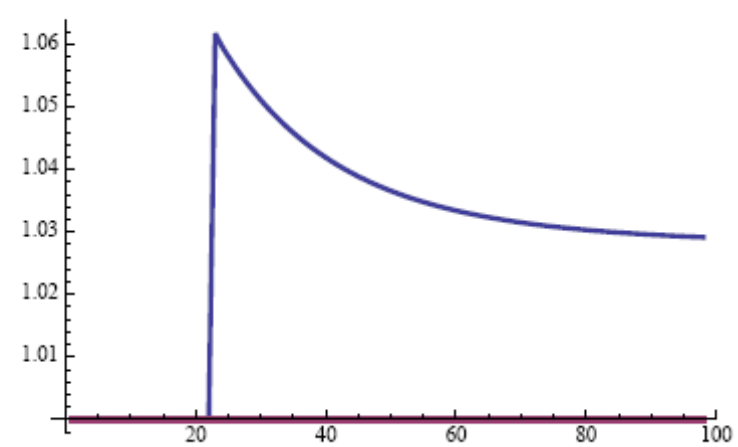

Figure 11. Employment

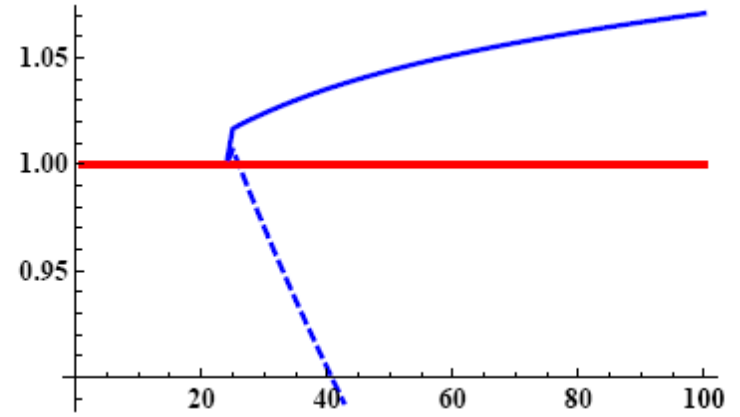

Figure 13. Wealth

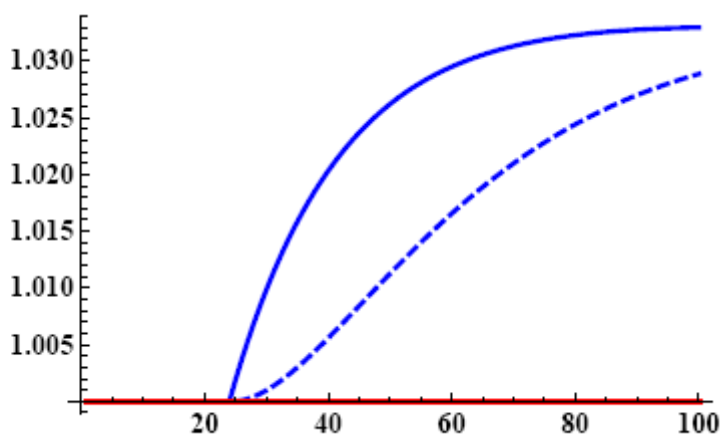

Note: Green Job (GJ, blue) vs. baseline (red) scenarios. Private unemployment decreases drastically after enabling the GJ scheme. Government spending increases by around 6 percent. The debt to GDP ratio has a sudden variation right after enacting GJ, but then stabilizes at a level 4 percent above the baseline case. The structural change in the 
economy can be observed in the employment level in both widget (solid line) and energy (dashed line) production sectors. While employment in the widget sector increases, it decreases in the energy industry. Both income and wealth increase for wage earners (solid lines) and capitalists (dashed lines).

\subsection{Employer-of-Last-Resort vs. Keynesian Demand Spur}

The second set of simulations analyzes the effects of two employment policies: the "traditional" Keynesian demand spur (hereafter KDS) through increased government spending, and an employer-of-last-resort (ELR) scheme. In this analysis, the structural effect of ELR through energy saving (20) and (21) is not implemented in order to analyze only the employment effect through a new steady state reach. ${ }^{21}$ The two simulations are conducted in the same way: at time 25 , the policy is enacted. The policies consist of a realized increase of total government spending of 6 percent, an increase which is devoted to either an increase in both energy and widget consumption (in the KDS case) or to the wage paid to unemployed workers (in the ELR case).

Figures 14, 15, 16, 17, 18, and 19 show the results obtained for these simulations. In all graphs, the blue line represents the ELR results while the red line represents KDS ones. All the results are relative changes from steady state values.

Evidently, the impact on GDP by the KDS is stronger as the whole increase in government budget is directly used to increase production, while in the case of ELR, part of that increase is saved by ELR workers. Furthermore, the Keynesian multiplier on public spending is higher than one. The debt to GDP ratio is thus lower in the KDS case; it is even lower than before the policy was enacted. Since GDP increases more so in the KDS case (4.5 percent) than in the ELR case (3 percent), private unemployment decreases more so in the first case than in the second (30 percent reduction versus 15 percent reduction). In the ELR case, however, involuntary unemployment is totally removed since the green-job program hires privately unemployed workers.

An interesting point regarding income and wealth of all households sectors: Both income and wealth increase more so in the ELR case (blue line) than in the KDS case (red line). At first, the impact is stronger on wage earners' (solid lines) income and wealth, clearly showing that the ELR is more efficient than the KDS as a poverty alleviation policy. By directing an increase in income toward the poorest share of the population, the ELR not only alleviates unemployment, but also directly improves wage earners' standard of living. What is more, this growth in income

\footnotetext{
${ }^{21}$ As seen in the previous subsection, equations (20) and (21) impede the model to reach a steady state.
} 
trickles down to capitalists' (dashed lines) income, making ELR a better policy for capitalists, as well.

Finally, ELR without its structural impacts implies a larger consumption of energy than a Keynesian Demand Spur. This is due to the fact that increased income for all household sectors implies larger energy consumption by these sectors. This underlines the fact that a greenjob ELR implying structural energy saving is mandatory if the Kyoto protocol is to be respected.

Two conclusions may be drawn from this analysis. First, the ELR is the fastest and most direct way to tackle unemployment and poverty. Targeting GDP or aggregate demand growth does improve the unemployment and poverty situation, but it is less efficient than the ELR regarding these objectives. Second, an increase in well-being for poor households implies an increase in energy either directly or indirectly through increase in widget consumption. This emphasizes the need for an energy saving policy such as the insulation part of the green-job ELR.

Figure 14. Unemployment

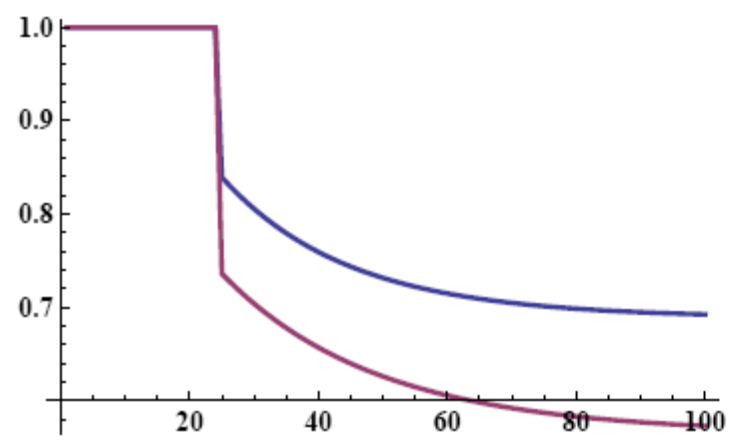

Figure 16. Debt to GDP

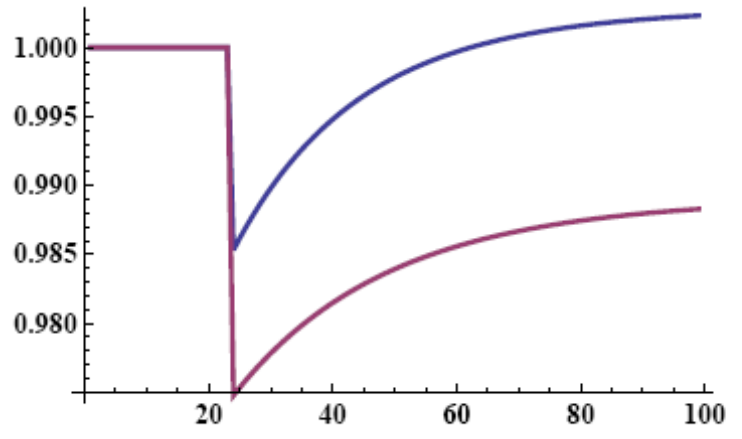

Figure 15. Government budget

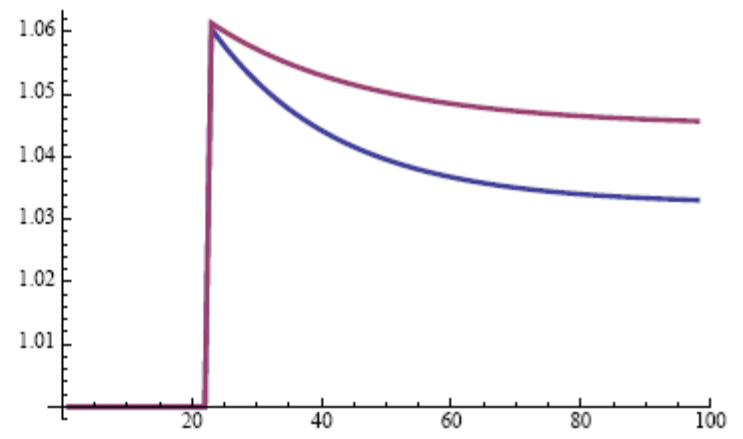

Figure 17. Income

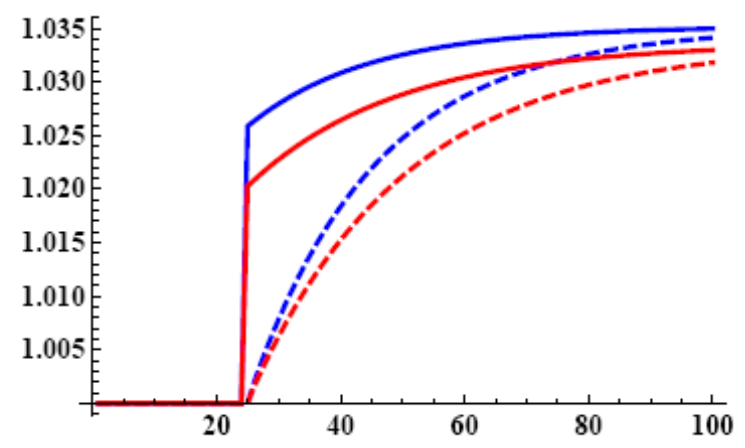


Figure 18. Widget - output

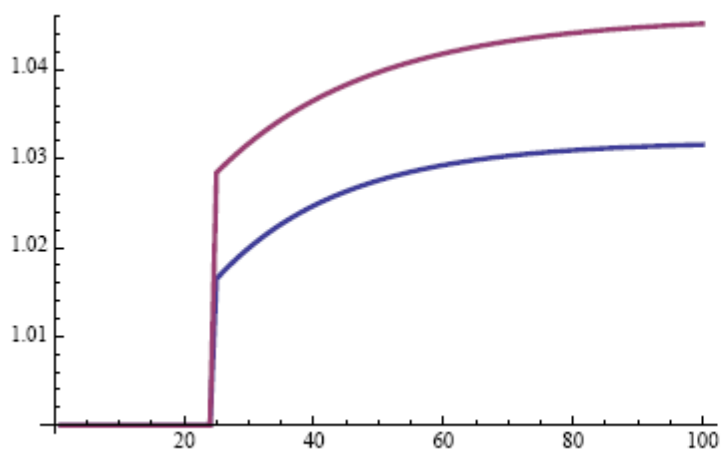

Figure 19. Energy - output

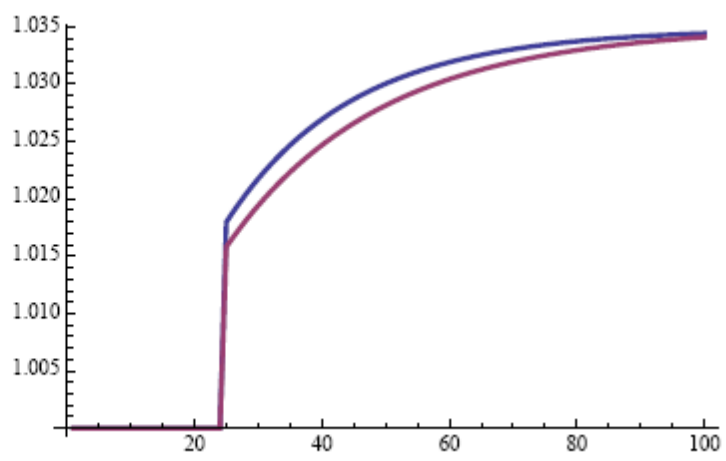

Note: Employer-of-last-resort (ELR, blue) vs. Keynesian demand spur (KDS, red) policies. Unemployment decreases more so and debt to GDP ratio is lower in the KDS case than in the ELR case. The budget increase is similar in both cases. Income increases under both policies, and for both wage earners (solid line) and capitalists (dashed line). However, impacts are stronger for the ELR. The ELR implies larger energy consumption than the KDS.

\section{CONCLUSION}

Unemployment is structurally present in a capitalist economy (Keynes 1936; Pasinetti 1993; Ros 2000). However, employment policies rarely target full employment (Papadimitriou 1999; Mitchell and Muyskens 2008). Usually these are "maximum employment possible under present situation" policies. We propose a job guarantee scheme that would eradicate unemployment and target lower energy consumption. Various analyses have shown that improved insulation in private and public buildings have a positive cost-benefit analysis.

The analysis done in this paper is based on a multi-sectorial stock-flow consistent model. This model allows us to observe output and pricing interdependencies. This is essential to show how structural changes in an industry affect other industries.

This paper shows that a green-job employer-of-last-resort is the best way to tackle unemployment and poverty, as it is directly targeted toward these issues. The implementation of an ELR would cost less than 6 percent of public spending (leading to a 0.4 percent increase in debt to GDP ratio). This proves that sustainable full employment could be achieved, improving the situation for all household sectors.

Furthermore, this program would imply a structural change in the economy toward energy efficiency. This is essential, as the increase in income and wealth for all household sectors would imply an increase of energy use. This proves the importance of public programs in order to imply changes that would otherwise not occur. Further work would include inflation modeling and adding a more elaborated finance sector. 


\section{REFERENCES}

Bellofiore, Riccardo, and Marco Passarella. 2010. "Minsky, the Monetary Circuit and the Current Crisis: A SFC Monetary Accounting Framework." Paper presented at the international conference, Can It Happen Again? Sustainable Policies to Mitigate and Prevent Financial Crises, University of Macerata, Italy, October.

Beveridge, William. 1945. Full Employment in a Free Society. New York, NY: Norton.

Chatelain, Jean-Bernard. 2010. "The Profit-Investment-Unemployment Nexus and Capacity Utilization in a Stock-Flow Consistent Model. Metroeconomica 61(3): 454-472.

Clinch, J. Petera, and John D. Healy. 2001. "Cost-Benefit Analysis of Domestic Energy Efficiency." Energy Policy 29(2): 113-124.

de Koning, J. 2001. "Aggregate Impact Analysis of Active Labour Market Policy: A Literature Review." International Journal of Manpower 22(7/8):707-735.

Dos Santos, C. H., and G. Zezza. 2004. "The Role of Monetary Policy in Post-Keynesian StockFow Consistent Macroeconomic Growth Models: Preliminary Results.” In M. Lavoie (ed.), Central Banking in the Modern World: Alternative Perspectives. Chetenham, UK: Edward Elgar.

. 2006. "Distribution and Growth in a Post-Keynesian Stock-Fow Consistent Model." In N. Salvadori (ed.), Economic Growth and Distribution. On the Nature and Causes of the Wealth of Nations. Cheltenham, UK: Edward Elgar.

—. 2008. "A Simplified, Benchmark, Stock-Flow Consistent Post- Keynesian Growth Model." Metroeconomica 59(3):441-78.

Dos Santos, Cláudio H., and Antonio Carlos Macedo e Silva. 2009. "Revisiting (and Connecting) Marglin-Bhaduri and Minsky: An SFC Look at Financialization and ProfitLed Growth.” Working Paper No. 567. Annandale-on-Hudson, NY: Levy Economics Institute of Bard College.

Eichner, Alfred S. 1976. The Megacorp and Oligopoly: Micro Foundations of Macro Dynamics. Cambridge, UK: Cambridge University Press.

Fazzari, Steven M., and Tracy L. Mott. 1986-1987. "The Investment Theories of Kalecki and Keynes: An Empirical Study of Firm Data, 1970-1982.” Journal of Post Keynesian Economics 9(2):171-187.

Foley, D., and L. Taylor. 2006. “A Heterodox Growth and Distribution Model.” In N. Salvadori (ed.), Economic Growth and Distribution. On the Nature and Causes of the Wealth of Nations. Cheltenham, UK: Edward Elgar.

Forstater, Mathew. 1998. "Flexible Full Employment: Structural Implications of Discretionary Public Sector Employment.” Journal of Economic Issues 32(2): 557-563. 
_ 2003. "Unemployment." In J.E. King (ed.), The Elgar Companion to Post Keynesian Economics. Cheltenham, UK: Edward Elgar.

_. 2006. "Green Jobs: Public Service Employment and Environmental Sustainability." Challenge 49(4):58-72.

Godley, Wynne, and Marc Lavoie. 2007. Monetary Economics: An Integrated Approach to Credit, Money, Income, Production, and Wealth. New York, NY: Palgrave MacMillan.

Haig, R.M. 1921. "The Concept of Income-Economic and Legal Aspects.” In R. M. Haig (ed.), The Federal Income Tax. New York, NY: Columbia University Press, 1-21.

Hens, H., G. Verbeeck, and B. Verdonck. 2001. "Impact of Energy Efficiency Measures on the $\mathrm{CO} 2$ Emissions in the Residential Sector, a Large Scale Analysis." Energy and Buildings 33(3):275-281.

Lee, Allen, Geophrey Syphers, Tami Rasmussen, and Alan Scott. 2000. Green City Buildings: Applying the LEED Rating System. Report prepared for the Portland Energy Office. Portland, OR: XENERGY Inc. and SERA Architects.

Kaboub, Fadhel. 2007. "Employment Guarantee Programs: A Survey of Theories and Policy Experiences." Working Paper No. 498. Annandale-on-Hudson, NY: Levy Economics Institute of Bard College.

Kaldor, N. 1968. "Productivity and Growth in Manufacturing Industry: A Reply." Economica 35: 385-391.

Kalecki, Michal. 1971. Selected Essays on the Dynamics of the Capitalist Economy. Cambridge, UK: Cambridge University Press.

Kats, G. 2006. Greening America's Schools-Costs and Benefits. Report prepared for Capital E. http://www.leed.us/ShowFile.aspx?DocumentID=2908

Kats, G., Perlman J, and S. Jamadagni. 2005. National Review of Green Schools: Costs, Benefits, and Implications for Massachusetts. Report prepared for the Massachusetts Technology Collaborative. http://www.azdeq.gov/ceh/download/natreview.pdf

Keynes, John Maynard. 1936. The General Theory of Employment, Interest, and Money. London, UK: Macmillan.

Kinsella, Stephen, Matthias Greiff, and Edward J. Nell. 2011. "Income Distribution in a StockFow Consistent Model with Education and Technological Change." Eastern Economic Journal 37(10:134-149.

Kostzer, Daniel. 2008. "Argentina: A Case Study on the Plan Jefes y Jefas de Hogar Desocupados, or the Employment Road to Economic Recovery." Working Paper No. 534. Annandale-on-Hudson, NY: Levy Economics Institute of Bard College. 
Lavoie, Marc. 1992. Foundations of Post-Keynesian Economic Analysis. Aldershot, UK: Edward Elgar.

Lavoie, Marc, and Wynne Godley. 2001-2002. "Kaleckian Models of Growth in a Coherent Stock-Flow Monetary Framework: A Kaldorian View." Journal of Post Keynesian Economics 24(2):277-311.

Lavoie, Marc, Gabriel Rodriguez, and Mario Seccareccia. 2004. "Similitudes and Discrepancies in Post-Keynesian and Marxist Theories of Investment: A Theoretical and Empirical Investigation." International Review of Applied Economics 18 (2):127-149.

Lee, F.S. 1998. Post-Keynesian Theory. Cambridge, UK: Cambridge University Press.

Lerner, A. P. 1944. The Economics of Control: Principles of Welfare Economics. New York, NY: Macmillan.

1951. Economics of Employment. Columbus, OH: McGraw-Hill.

Levine, M., L. Geng, D. Harvey, S. Lang, G. Levermore, D. Ürge-Vorsatz, K. Blok, A. Novikova, J. Rilling, H. Yoshino, A. Mongameli Mehlwana, and S. Mirasgedis. 2007. "Residential and Commercial Buildings." In B. Metz, O.R. Davidson, P.R. Bosch, R. Dave, L.A. Meyer (eds.), Climate Change 2007: Mitigation. Contribution of Working Group III to the Fourth Assessment Report of the Intergovernmental Panel on Climate Change. Cambridge, UK and New York, NY: Cambridge University Press.

Lieuw-Kie-Song, Maikel. 2010. "Green Jobs for the Poor: Why a Public Employment Approach is Needed Now." One Pager 105. The International Policy Centre for Inclusive Growth.

—. 2009. "Green Jobs for the Poor: A Public Employment Approach." Poverty Reduction Discussion Paper PG/2009/002. United Nation Development Programme.

Lunghini, G. 1995. L'età dello spreco. Disoccupazione e bisogni sociali. Torino: Bollati Boringhieri.

Martin, J. 1998. "What Works among Active Labour Market Policies: Evidence from OECD Countries' Experience.” OECD Labour Market and Social Policy Occasional Papers 35.

Minsky, H. P. 1986. Stabilizing an Unstable Economy. New Haven, CT: Yale University Press.

Mitchell, William. 2007. "Why Public Sector Job Creation Should be Fashionable." Working Paper No. 07-03. Newcastle, New South Wales, Australia: Centre of Full Employment and Equity.

Mitchell, William, and Joan Muyskens. 2008. "Full Employment Abandoned: Shifting Sands and Policy Failures." Working Paper No. 08-01. Newcastle, New South Wales, Australia: Centre of Full Employment and Equity.

Organisation for Economic Co-operation and Development (OECD). 2011. OECD.StatExtracts. http://stats.oecd.org/ 
Parliamentary Office of Science and Technology (POST). 2005. "Household Energy Efficiency." Postnote No. 249. London, UK: House of Parliament.

Papadimitriou, Dimitri P. 1999. "Full Employment Has Not Been Achieved.” Public Policy Brief No. 53. Annandale-on-Hudson, NY: Levy Economics Institute of Bard College.

Pasinetti, Luigi L. 1981. Structural Change and Economic Growth: A Theoretical Essay on the Dynamics of the Wealth of Nations. Cambridge, UK: Cambridge University Press.

-1993. Structural Economic Dynamics: A Theory of the Economic Consequences of Human Learning. Cambridge, UK: Cambridge University Press.

Passarella, Marco. 2010. "Minsky Beyond Minsky." Paper presented at the 14th Conference of the Research Network Macroeconomics and Macroeconomic Policies (FMM), Stabilising an Unequal Economy? Public Debt, Financial Regulation, and Income Distribution, Berlin, Germany, October.

Robinson, Joan. 1969. “A Further Note.” The Review of Economic Studies 36(2):260-262.

Ros, Jaime. 2000. Development Theory and the Economics of Growth. Ann Arbor, MI: The University of Michigan Press.

Schumpeter, J. A. 1934/1912. The Theory of Economic Development. Cambridge, MA: Harvard University Press.

Seppecher, Pascal. 2010. "Flexibility of Wages and Macroeconomic Instability in an AgentBased Computational Model with Endogenous Money." Paper presented at the Society for Economic Science with Heterogeneous Interacting Agents Workshop on Economic Heterogeneous Interacting Agents (ESHIA/WEHIA), University of Eastern Piedmont, Alessandria, Italy, June.

Simons, H.C. 1938. Personal Income Taxation: The Definition of Income as a Problem of Fiscal Policy. Chicago, Il: Chicago University Press.

Steindl, Josef. 1952. Maturity and Stagnation in American Capitalism. Oxford, UK: Blackwell.

Taylor, Lance. 2008. “A Foxy Hedgehog: Wynne Godley and Macroeconomic Modeling." Cambridge Journal of Economics 32(4): 639-663.

United Nations Conference on Trade and Development (UNCTAD). 2010. Trade and Development Report. Employment, Globalization and Development. Report by the secretariat of the United Nations Conference on Trade and Development. United Nations: New York, NY, USA and Geneva, Switzerland.

United Nations Environment Programme (UNEP). 2008. Green Jobs: Towards Decent Work in a Sustainable Low-Carbon World. Report. http://www.unep.org/labour_environment/PDFs/Greenjobs/UNEP-Green-JobsReport.pdf 
Wray, L. Randall. 1998. Understanding Modern Money: They Key to Full Employment and Price Stability. Cheltenham, UK and Northampton, MA, USA: Edward Elgar. . 2007. "The Employer-of-Last-Resort Programme: Could It Work for Developing Countries?" Economic and Labour Market Papers 2007/5. Geneva, Switzerland: International Labour Office. 


\section{APPENDIX A: NOTATIONS}

\section{Variables}

\begin{tabular}{|c|l|}
\hline$Y D_{x}$ & Nominal disposable income of sector $x$ \\
\hline$y d_{x}$ & Real disposable income of sector $x$ \\
\hline$C_{x, y}$ & Nominal consumption from sector $x$ of good $y$ \\
\hline$c_{x, y}$ & Real consumption from sector $x$ of good $y$ \\
\hline$M_{x}$ & Money deposits of household sector $x$ \\
\hline$B_{x}$ & Bonds holding of household sector $x$ \\
\hline$V_{x}$ & Nominal wealth of sector $x$ \\
\hline$V_{f, x}$ & Financial wealth of household sector $x$ \\
\hline$v_{x}$ & Real wealth of household sector $x$ \\
\hline$c p i_{x}$ & Consumer price index of sector $x$ \\
\hline$\pi_{x}$ & Inflation related to consumer price index of sector $x$ \\
\hline$Y_{y}$ & Nominal output of sector $y$ \\
\hline$y_{y}$ & Real output of sector $y$ \\
\hline$y_{f c, y}$ & Full capacity output of sector $y$ \\
\hline$u_{y}$ & Capacity utilisation rate of sector $y$ \\
\hline$i_{y}$ & Real investment of sector $y$ \\
\hline$g_{k, y}$ & Capital growth rate of sector $y$ \\
\hline$p_{y}$ & Price of good $y$ \\
\hline$F_{y}$ & Profits in sector $y$ \\
\hline$R E_{y}$ & Retained earnings in sector $y$ \\
\hline$U C_{y}$ & Unit cost of good $y$ \\
\hline$\theta_{y}$ & Profits related part of sector $y$ mark-up \\
\hline$\phi_{y}$ & Retained earnings related part of sector $y$ mark-up \\
\hline$\rho_{y}$ & Borrowed share of investment of sector $y$ \\
\hline$\lambda_{y}$ & Leverage rate of sector $y$ \\
\hline$L_{y}$ & Total loans in sector $y$ \\
\hline$V_{y}$ & Net wealth in sector $y$ \\
\hline$N_{y}$ & Employment in sector $y$ \\
\hline$L$ & Total loans \\
\hline$M$ & Total cash holding \\
\hline$B_{b}$ & Bonds held by banks \\
\hline$F_{b}$ & Banks profits \\
\hline$U$ & Total unemployment \\
\hline$G$ & Total public spending \\
\hline$T$ & Total taxes receipt \\
\hline$T_{x}$ & Taxes of sector $x$ \\
\hline$B_{s}$ & Bonds supply \\
\hline$B_{d}$ & Bonds demand \\
\hline & \\
\hline
\end{tabular}




\section{Parameters}

\begin{tabular}{|c|c|c|}
\hline$\alpha_{h, 0}$ & Autonomous consumption for wage earners & 0 \\
\hline$\alpha_{h, 1}$ & Propensity to consume for wage earners based on its real disposable income & 0.726 \\
\hline$\alpha_{h, 2}$ & Propensity to consume for wage earners based on its real wealth & 0.07 \\
\hline$\alpha_{c a, 0}$ & Autonomous consumption for capitalists & 0 \\
\hline$\alpha_{c a, 1}$ & Propensity to consume for capitalists based on its real disposable income & 0.726 \\
\hline$\alpha_{c a, 2}$ & Propensity to consume for capitalists based on its real wealth & 0.04 \\
\hline$\beta_{h}$ & Energy consumption preference for wage earners & 0.085 \\
\hline$c_{h, e}^{\min }$ & Minimum energy consumption for wage earners & 0 \\
\hline$c_{h, w}^{\min }$ & Minimum widget consumption for wage earners & 0 \\
\hline$\lambda_{h, 0}$ & Minimum share of wealth hold as bonds for wage earners & 0.1 \\
\hline$\lambda_{h, 1}$ & Propensity to hold wealth for wage earners based on bonds interest rate & 0.1 \\
\hline$\beta_{c a}$ & Energy consumption preference for capitalists & 0.085 \\
\hline$c_{c a, e}^{\min }$ & Minimum energy consumption for capitalists & 0 \\
\hline$c_{c a, w}^{\min }$ & Minimum widget consumption for capitalists & 0 \\
\hline$\lambda_{c a, 0}$ & Minimum share of wealth hold as bonds for capitalists & 0.3 \\
\hline$\lambda_{c a, 1}$ & Propensity to hold wealth for capitalists based on bonds interest rate & 0.2 \\
\hline$\theta_{h}$ & Tax rate for wage earners & 0.14 \\
\hline$\theta_{c a}$ & Tax rate for capitalists & 0.07 \\
\hline$p r_{n, e}$ & Labor productivity in energy sector & 109355.8 \\
\hline$p r_{i, e}$ & Capital productivity in energy sector & 98.913 \\
\hline$p r_{n, i}$ & Labor productivity in capital good sector & 101816.1 \\
\hline$p r_{e, i}$ & Energy productivity in capital good sector & 93.998 \\
\hline$p r_{i, i}$ & Capital productivity in capital good sector & 116.532 \\
\hline$p r_{n, w}$ & Labor productivity in widget sector & 82801.08 \\
\hline$p r_{e, w}$ & Energy productivity in widget sector & 95.407 \\
\hline$p r_{i, w}$ & Capital productivity in widget sector & 106.278 \\
\hline$\gamma_{0}$ & Minimum capital growth & 0 \\
\hline$\gamma_{1}$ & Desired increase in capital growth based on capacity utilisation rate & 1 \\
\hline$\delta$ & Depreciation rate of capital & 0.1 \\
\hline$\lambda^{T}$ & Targeted leverage level & 0.8 \\
\hline$u^{T}$ & Targeted capacity utilisation rate & 0.75 \\
\hline$r_{s}$ & Return on capital & 0.03 \\
\hline$r_{l}$ & Interest rate on loans & 0.04 \\
\hline$r_{b}$ & Interest rate on bonds & 0.01 \\
\hline$G_{T}$ & Unemployment benefit & 11882 \\
\hline$W_{E L R}$ & ELR wage & 24685 \\
\hline$W_{e}$ & Nominal wage in energy sector & 61753 \\
\hline$W_{i}$ & Nominal wage in capital good sector & 63481 \\
\hline$W_{w}$ & Nominal wage in widget sector & 58722 \\
\hline $\bar{N}$ & Total labor force & 154142000 \\
\hline$C_{g, e}$ & Energy consumption by public sector & $7.910^{9}$ \\
\hline$C_{g, w}$ & Widget consumption by public sector & $6.910^{11}$ \\
\hline$\xi_{h}$ & Green job impact on household energy consumption & 0.1 \\
\hline$\xi_{g}$ & Green job impact on public energy consumption & 1 \\
\hline
\end{tabular}




\section{APPENDIX B: MODEL EQUATIONS}

\section{Wage Earners}

$$
\begin{aligned}
Y D_{h} & =\left(1-\theta_{h}\right)\left[W_{e} N_{e}+W_{w} N_{w}+W_{i} N_{i}\right]+\overline{G_{T}} U+r_{b} B_{h,-1} \\
c p i_{h} & =\beta_{h} p_{e}+\left(1-\beta_{h}\right) p_{w} \\
\pi_{h} & =\frac{c p i_{h}-c p i_{h,-1}}{c p i_{h,-1}} \\
y d_{h}^{h s} & =\frac{Y D_{h}}{c p i_{h}}-\frac{\pi_{h} V_{h,-1}}{c p i_{h}} \\
c_{h} & =\alpha_{h, 0}+\alpha_{h, 1} y d_{h}+\alpha_{h, 2} v_{h,-1} \\
C_{h} & =c_{h} c p i_{h} \\
c_{h, e} & =c_{h, e}^{\min }+\beta_{h} \frac{C_{h}-c_{h, e}^{\min } p_{e}-c_{h, w}^{\min } p_{w}}{p_{e}} \\
c_{h, w} & =c_{h, w}^{\min }+\left(1-\beta_{h}\right) \frac{C_{h}-c_{h, e}^{\min } p_{e}-c_{h, w}^{\min } p_{w}}{p_{w}} \\
\Delta V_{h} & =Y D_{h}-C_{h} \\
B_{h} & =\lambda_{h, 0}+\lambda_{h, 1} r b \\
V_{h,-1} & \\
M_{h} & =V_{h}-B_{h}
\end{aligned}
$$

\section{Capitalists}

$$
\begin{aligned}
Y D_{c a} & =\left(1-\theta_{c a}\right)\left[F_{e}+F_{w}+F_{i}+F_{b}\right]+r_{b} B_{c a,-1} \\
c p i_{c a} & =\beta_{c a} p_{e}+\left(1-\beta_{c a}\right) p_{w} \\
\pi_{c a} & =\frac{c p i_{c a}-c p i_{c a,-1}}{c p i_{c a,-1}} \\
y d_{c a}^{h s} & =\frac{Y D}{c p i_{c a}}-\frac{\pi_{c a} V_{c a,-1}}{c p i_{c a}} \\
c_{c a} & =\alpha_{c a, 0}+\alpha_{c a, 1} y d_{h}+\alpha_{c a, 2} v_{c a,-1} \\
C_{c a} & =c_{c a} c p i_{c a} \\
c_{c a, e} & =c_{c a, e}^{m i n}+\beta_{c a} \frac{C_{c a}-c_{c a, e}^{m i n} p_{e}-c_{c a, w}^{m i n} p_{w}}{p_{e}} \\
c_{c a, w} & =c_{c a, w}^{m i n}+\left(1-\beta_{c a}\right) \frac{C_{c a}-c_{c a, e}^{m i n} p_{e}-c_{c a, w}^{m i n} p_{w}}{p_{w}} \\
V_{c a} & =V_{f c a}+V_{e}+V_{w}+V_{i} \\
\Delta V_{f c a} & =Y D_{c a}-C_{c a} \\
B_{c a} & =\lambda_{c a, 0}+\lambda_{c a, 1} r b \\
V_{f c a,-1} & M_{c a}=V_{f c a}-B_{c a}
\end{aligned}
$$




\section{Demand}

$$
\begin{aligned}
y_{e} & =c_{h, e}+c_{c a, e}+c_{w, e}+c_{g, e}+c_{i, e} \\
y_{i} & =i_{e}+i_{w}+i_{i} \\
y_{w} & =c_{h, w}+c_{c a, w}+c_{g, w} \\
c_{w, e} & =\frac{y_{w}}{p r_{e, w}} \\
c_{i, e} & =\frac{y_{i}}{p r_{e, i}}
\end{aligned}
$$

\section{Employment}

$$
\begin{aligned}
N_{e} & =\frac{y_{e}}{p r_{n, e}} \\
N_{w} & =\frac{y_{w}}{p r_{n, w}} \\
N_{i} & =\frac{y_{i}}{p r_{n, i}} \\
U & =\bar{N}-N_{e}-N_{i}-N_{w}
\end{aligned}
$$

\section{Investments}

$$
\begin{aligned}
g_{k, e} & =\gamma_{0}+\gamma_{1}\left(u_{e}-u^{T}\right) \\
u_{e} & =\frac{y_{e}}{y_{f c, e}} \\
y_{f c, e} & =k_{e,-1} p r_{k, e} \\
i_{e} & =\max \left[g_{k, e}+\delta, 0\right] k_{e,-1} \\
\Delta k_{e} & =i_{e}-\delta k_{e,-1} \\
g_{k, i} & =\gamma_{0}+\gamma_{1}\left(u_{i}-u^{T}\right) \\
u_{i} & =\frac{y_{i}}{y_{f c, i}} \\
y_{f c, i} & =k_{i,-1} p r_{k, i} \\
i_{i} & =\max \left[g_{k, i}+\delta, 0\right] k_{i,-1} \\
\Delta k_{i} & =i_{i}-\delta k_{i,-1} \\
g_{k, w} & =\gamma_{0}+\gamma_{1}\left(u_{w}-u^{T}\right) \\
u_{w} & =\frac{y_{w}}{y_{f c, w}} \\
y_{f c, w} & =k_{w,-1} p r_{k, w} \\
i_{w} & =\max \left[g_{k, w}+\delta, 0\right] k_{w,-1} \\
\Delta k_{w} & =i_{w}-\delta k_{w,-1}
\end{aligned}
$$

\section{Costs}




$$
\begin{aligned}
U C_{e} & =z_{2, e} \frac{W_{e} N_{e}+r_{l} L_{e,-1}}{y_{e}}+\left(1-z_{2, e}\right)\left(1-z_{3, e}\right) \frac{W_{e} N_{e}+r_{l} L_{e,-1}+\delta p_{k} k_{e,-1}}{y_{e}}+z_{3, e}\left[\beta_{e}+\alpha_{e}\left(y_{e}-y_{f c, e}\right)^{2}\right] \\
z_{2, e} & =1 \text { if } u_{e}<u_{\min } \\
z_{3, e} & =1 \text { if } u_{e}>1 \\
U C_{i} & =z_{2, i} \frac{W_{i} N_{i}+c_{i, e} p_{e}+r_{l} L_{i,-1}}{y_{i}}+\left(1-z_{2, i}\right)\left(1-z_{3, i}\right) \frac{W_{i} N_{i}+c_{i, e} p_{e}+r_{l} L_{i,-1}+\delta p_{k} k_{i,-1}}{y_{i}}+\ldots \\
& \ldots+z_{3, i}\left[\beta_{i}+\alpha_{i}\left(y_{i}-y_{f c, i}\right)^{2}\right] \\
z_{2, i} & =1 \text { if } u_{i}<u_{\min } \\
z_{3, i} & =1 \text { if } u_{i}>1 \\
U C_{w} & =z_{2, w} \frac{W_{w} N_{w}+c_{w, e} p_{e}+r_{l} L_{w,-1}}{y_{w}}+\left(1-z_{2, w}\right)\left(1-z_{3, w}\right) \frac{W_{w} N_{w}+c_{w, e} p_{e}+r_{l} L_{w,-1}+\delta p_{k} k_{w,-1}}{y_{w}}+\ldots \\
& \ldots+z_{3, w}\left[\beta_{w}+\alpha_{w}\left(y_{w}-y_{f c, w}\right)^{2}\right] \\
z_{2, w} & =1 \text { if } u_{w}<u_{\min } \\
z_{3, w} & =1 \text { if } u_{w}>1
\end{aligned}
$$




\section{Prices}

$$
\begin{aligned}
& p_{e}=\left(1+\theta_{e}+\phi_{e}\right) U C_{e} \\
& F_{e}=r_{s} p_{k} k_{e,-1} \\
& \theta_{e}=\frac{r_{s} p_{k} k_{e,-1}}{U C\left(y_{e}^{e}\right) y_{e}^{e}} \\
& \lambda_{e}=\frac{L_{e}}{p_{k} k_{e}} \\
& \rho_{e}=\max \left[\frac{\lambda^{T} p_{k} k_{e,-1}+i_{e}-L_{e,-1}}{i_{e}}, 0\right] \\
& R E_{e}^{e}=\phi_{e} U C\left(y_{e}^{e}\right) y_{e}^{e} \\
& \phi_{e}=\frac{g_{k, e} k_{e,-1} p_{k}}{\left(1+\rho_{e}\right) U C\left(y_{e}^{e}\right) y_{e}^{e}}+z_{1, e} \frac{L_{e,-1}-\lambda^{T} p_{k} k_{e,-1}+i_{e}}{U C\left(y_{e}^{e}\right) y_{e}^{e}} \\
& z_{1, e}=1 \text { if } \rho_{e}=0 \\
& y_{e}^{e}=y_{e,-1}\left(1-\hat{p_{e}}\right) \\
& p_{i}=\left(1+\theta_{i}+\phi_{i}\right) U C_{i} \\
& F_{i}=r_{s} p_{k} k_{i,-1} \\
& \theta_{i}=\frac{r_{s} p_{k} k_{i}}{U C_{i}^{e} y_{i}^{e}} \\
& \lambda_{i}=\frac{L_{i}}{p_{k} k_{i}} \\
& \rho_{i}=\max \left[\frac{\lambda^{T} p_{k} k_{i,-1}+i_{i}-L_{i,-1}}{i_{i}}, 0\right] \\
& R E_{i}^{e}=\phi_{i} U C\left(y_{i}^{e}\right) y_{i}^{e} \\
& \phi_{i}=\frac{g_{k, i} k_{i,-1} p_{k}}{\left(1+\rho_{i}\right) U C\left(y_{i}^{e}\right) y_{i}^{e}}+z_{1, i} \frac{L_{i,-1}-\lambda^{T} p_{k} k_{i,-1}+i_{i}}{U C\left(y_{i}^{e}\right) y_{i}^{e}} \\
& z_{1, i}=1 \text { if } \rho_{i}=0 \\
& y_{i}^{e}=y_{i,-1}\left(1-\hat{p}_{i}\right) \\
& p_{w}=\left(1+\theta_{w}+\phi_{w}\right) U C_{w} \\
& F_{w}=r_{s} p_{k} k_{w,-1} \\
& \theta_{w}=\frac{r_{s} p_{k} k_{w}}{U C_{w}^{e} y_{w}^{e}} \\
& \lambda_{w}=\frac{L_{w}}{p_{k} k_{w}} \\
& \rho_{w}=\max \left[\frac{\lambda^{T} p_{k} k_{w,-1}+i_{w}-L_{w,-1}}{i_{w}}, 0\right] \\
& R E_{w}^{e}=\phi_{w} U C\left(y_{w}^{e}\right) y_{w}^{e} \\
& \phi_{w}=\frac{g_{k, w} k_{w,-1} p_{k}}{\left(1+\rho_{w}\right) U C\left(y_{w}^{e}\right) y_{w}^{e}}+z_{1, w} \frac{L_{w,-1}-\lambda^{T} p_{k} k_{w,-1}+i_{w}}{U C\left(y_{w}^{e}\right) y_{w}^{e}} \\
& z_{1, w}=1 \text { if } \rho_{w}=0 \\
& y_{w}^{e}=y_{w,-1}\left(1-\hat{p_{w}}\right)
\end{aligned}
$$

\section{Finance}




$$
\begin{aligned}
R E_{e} & =\phi_{e} U C_{e} y_{e} \\
\Delta L_{e} & =p_{k} i_{e}-R E_{e} \\
V_{e} & =p_{k} k_{e}-L_{e} \\
R E_{i} & =\phi_{i} U C_{i} y_{i} \\
\Delta L_{i} & =p_{k} i_{i}-R E_{i} \\
V_{i} & =p_{k} k_{i}-L_{i} \\
R E_{w} & =\phi_{w} U C_{w} y_{w} \\
\Delta L_{w} & =p_{k} i_{w}-R E_{w} \\
V_{w} & =p_{k} k_{w}-L_{w}
\end{aligned}
$$

\section{Banking Sector}

$$
\begin{aligned}
\Delta M & =\Delta M_{h}+\Delta M_{c a} \\
\Delta L & =\Delta L_{e}+\Delta L_{w}+\Delta L_{i} \\
\Delta B_{b} & =\Delta M-\Delta L \\
F_{b} & =r_{l}\left(L_{e,-1}+L_{w,-1}+L_{i,-1}\right)+r_{b} B_{b,-1}
\end{aligned}
$$

\section{Government Sector}

$$
\begin{aligned}
T & =\theta_{h}\left[W_{e} N_{e}+W_{w} N_{w}+W_{i} N_{i}\right]+\theta_{c a}\left[F_{e}+F_{w}+F_{i}+F_{b}\right] \\
G & =C_{g, e}+C_{g, w}+\overline{G_{T}} U+r_{b} B_{s,-1} \\
c_{g, e} & =\frac{\overline{C_{g, e}}}{p_{e}} \\
c_{g, w} & =\frac{\overline{C_{g, w}}}{p_{w}} \\
\Delta B_{d} & =\Delta B_{b}+\Delta B_{h}+\Delta B_{c a} \\
\Delta B_{s} & =G-T
\end{aligned}
$$




\section{APPENDIX C: STEADY STATE}

\section{System of Equations}

a. Prices

$$
\begin{aligned}
& p_{k}^{\star}\left(\delta+r_{l} \lambda^{T}+r_{s}\right)=p_{e}^{\star} u_{e}^{\star} p r_{e, i}-\frac{W_{e} u_{e}^{\star} p r_{e, i}}{p r_{e, n}} \\
& p_{k}^{\star}\left(\delta+r_{l} \lambda^{T}+r_{s}\right)=p_{k}^{\star} u_{i}^{\star} p r_{i, i}-\frac{W_{i} u_{i}^{\star} p r_{i, i}}{p r_{i, n}}-\frac{p_{e}^{\star} u_{i}^{\star} p r_{i, i}}{p r_{i, e}} \\
& p_{k}^{\star}\left(\delta+r_{l} \lambda^{T}+r_{s}\right)=p_{w}^{\star} u_{w}^{\star} p r_{w, i}-\frac{W_{w} u_{w}^{\star} p r_{w, i}}{p r_{w, n}}-\frac{p_{e}^{\star} u_{w}^{\star} p r_{w, i}}{p r_{w, e}}
\end{aligned}
$$

b. Wealth, Income, and Consumption

$$
\begin{aligned}
& k_{i}^{\star} u_{i}^{\star} p r_{i, i}=\delta\left(k_{i}^{\star}+k_{e}^{\star}+k_{w}^{\star}\right) \\
& u_{e}^{\star} k_{e}^{\star} p r_{e, i}=\frac{C_{g, e}}{p_{e}^{\star}}+\frac{u_{i}^{\star} p r_{i, i} k_{i}^{\star}}{p r_{i, e}}+\frac{u_{w}^{\star} p r_{w, i} k_{w}^{\star}}{p r_{w, e}}+\frac{\beta_{h}}{p_{e}^{\star}} Y D_{h}^{\star}+\frac{\beta_{c a}}{p_{e}^{\star}} Y D_{c a}^{\star} \\
& u_{w}^{\star} k_{w}^{\star} p r_{w, i}=\frac{C_{g, w}}{p_{w}^{\star}}+\frac{1-\beta_{h}}{p_{w}^{\star}} Y D_{h}^{\star}+\frac{1-\beta_{c a}}{p_{w}^{\star}} Y D_{c a}^{\star} \\
& V_{h}^{\star}=\frac{1-\alpha_{h, 1}}{\alpha_{h, 2}} Y D_{h}^{\star} \\
& M_{h}^{\star}=\left(1-\lambda_{h, 0}-\lambda_{h, 1} r b\right) V_{h}^{\star} \\
& B_{h}^{\star}=\left(\lambda_{h, 0}+\lambda_{h, 1} r b\right) V_{h}^{\star} \\
& V_{c a}^{\star}=V_{f c a}^{\star}+(1-\lambda) p_{k}^{\star}\left(k_{e}^{\star}+k_{i}^{\star}+k_{w}^{\star}\right) \\
& B_{c a}^{\star}=\left(\lambda_{c a, 0}+\lambda_{c a, 1} r_{b}\right) V_{f c a}^{\star} \\
& V_{c a}^{\star}=\frac{1-\alpha_{c a, 1}}{\alpha_{c a, 2}} Y D_{c a}^{\star} \\
& M_{c a}^{\star}=\left(1-\lambda_{c a, 0}-\lambda_{c a, 1} r_{b}\right) V_{f c a}^{\star} \\
& Y D_{c a}^{\star}=\left(1-t_{c a}\right)\left(p_{k}^{\star}\left(k_{e}^{\star}+k_{i}^{\star}+k_{w}^{\star}\right)\left(r_{s}+\lambda^{T}\left(r_{l}-r_{b}\right)\right)+r_{b}\left(M_{h}^{\star}+M_{c a}^{\star}\right)\right)+r_{b} B_{c a}^{\star}(77) \\
& Y D_{h}^{\star}\left(1-r_{b}\left(\lambda_{h, 0}+r_{b} \lambda_{h, 1}\right) \frac{1-\alpha_{h, 1}}{\alpha_{h, 2}}\right)=\frac{u_{e}^{\star} p r_{e, i}}{p r_{e, n}} k_{e}^{\star}\left(\left(1-\theta_{h}\right) W_{e}-G^{T}\right)+\frac{u_{i}^{\star} p r_{i, i}}{p r_{i, n}} k_{i}^{\star}\left(\left(1-\theta_{h}\right) W_{i}-G^{T}\right) \ldots \\
& \ldots \ldots \frac{u_{w}^{\star} p r_{w, i}}{p r_{w, n}} k_{w}^{\star}\left(\left(1-\theta_{h}\right) W_{w}-G^{T}\right)+G^{T} \bar{N}
\end{aligned}
$$




\section{Steps}

a. Prices - Energy sector

$$
\begin{aligned}
i_{e}^{\star} p_{k}^{\star} & =R E_{e}^{\star} \\
& =Y_{e}^{\star}-W_{e} N_{e}^{\star}-r_{l} L_{e}^{\star}-r_{s} p_{k}^{\star} k_{e}^{\star} \\
& =\left(p_{e}^{\star}-\frac{W_{e}}{p r_{e, n}}\right) y_{e}^{\star}-p_{k}^{\star} k_{e}^{\star}\left(r_{l} \lambda+r_{s}\right) \\
\delta k_{e}^{\star} p_{k}^{\star} & =\left(p_{e}^{\star}-\frac{W_{e}}{p r_{e, n}}\right) u^{T} p r_{e, i} k_{e}^{\star}-p_{k}^{\star} k_{e}^{\star}\left(r_{l} \lambda+r_{s}\right) \\
\left(\delta+r_{l} \lambda+r_{s}\right) p_{k}^{\star} & =p_{e}^{\star} u^{T} p r_{e, i}-\frac{W_{e} u^{T} p r_{e, i}}{p r_{e, n}}
\end{aligned}
$$

\section{b. Prices-Capital good sector}

$$
\begin{gathered}
i_{i}^{\star} p_{k}^{\star}=R E_{i}^{\star} \\
=Y_{i}^{\star}-W_{i} N_{i}^{\star} c_{i, e}^{\star} p_{e}^{\star}-r_{l} L_{i}^{\star}-r_{s} p_{k}^{\star} k_{i}^{\star} \\
=\left(p_{i}^{\star}-\frac{W_{i}}{p r_{i, n}}-\frac{p_{e}^{\star}}{p r_{i, e}}\right) y_{i}^{\star}-p_{k}^{\star} k_{i}^{\star}\left(r_{l} \lambda+r_{s}\right) \\
\delta k_{i}^{\star} p_{k}^{\star}=\left(p_{i}^{\star}-\frac{W_{i}}{p r_{i, n}}-\frac{p_{e}^{\star}}{p r_{i, e}}\right) u^{T} p r_{i, i} k_{i}^{\star}-p_{k}^{\star} k_{i}^{\star}\left(r_{l} \lambda+r_{s}\right) \\
\left(\delta+r_{l} \lambda+r_{s}\right) p_{k}^{\star}=p_{i}^{\star} u^{T} p r_{i, i}-\frac{W_{i} u^{T} p r_{i, i}}{p r_{i, n}}-\frac{p_{e}^{\star} u^{T} p r_{i, i}}{p r_{i, e}}
\end{gathered}
$$

\section{c. Prices - Widget sector}

$$
\begin{aligned}
i_{w}^{\star} p_{k}^{\star} & =R E_{w}^{\star} \\
& =Y_{w}^{\star}-W_{w} N_{w}^{\star} c_{w, e}^{\star} p_{e}^{\star}-r_{l} L_{w}^{\star}-r_{s} p_{k}^{\star} k_{w}^{\star} \\
& =\left(p_{w}^{\star}-\frac{W_{w}}{p r_{w, n}}-\frac{p_{e}^{\star}}{p r_{w, e}}\right) y_{w}^{\star}-p_{k}^{\star} k_{w}^{\star}\left(r_{l} \lambda+r_{s}\right) \\
\delta k_{w}^{\star} p_{k}^{\star} & =\left(p_{w}^{\star}-\frac{W_{w}}{p r_{w, n}}-\frac{p_{e}^{\star}}{p r_{w, e}}\right) u^{T} p r_{w, i} k_{w}^{\star}-p_{k}^{\star} k_{w}^{\star}\left(r_{l} \lambda+r_{s}\right) \\
\left(\delta+r_{l} \lambda+r_{s}\right) p_{k}^{\star} & =p_{w}^{\star} u^{T} p r_{w, i}-\frac{W_{w} u^{T} p r_{w, i}}{p r_{w, n}}-\frac{p_{e}^{\star} u^{T} p r_{w, i}}{p r_{w, e}}
\end{aligned}
$$


d. Wealth, Income, and Consumption - Wage earners

$$
\begin{aligned}
& C_{h}^{\star}= Y D_{h}^{\star} \\
& Y D_{h}^{\star}= \frac{\alpha_{h, 2}}{1-\alpha_{h, 1}} V_{h}^{\star} \\
& B_{h}^{\star}=\left(\lambda_{h, 0}+\lambda_{h, 1} r_{b}\right) V_{h}^{\star} \\
& Y D_{h}^{\star}=\left(1-\theta_{h}\right)\left[W_{e} N_{e}^{\star}+W_{w} N_{w}^{\star}+W_{i} N_{i}^{\star}\right]+\overline{G_{T}}\left(\bar{N}-N_{e}^{\star}+N_{i}^{\star}+N_{w}^{\star}\right)+r_{b} B_{h}^{\star} \\
& Y D_{h}^{\star}= \frac{u_{e}^{\star} p r_{e, i}}{p r_{e, n}} k_{e}^{\star}\left(\left(1-\theta_{h}\right) W_{e}-G^{T}\right)+\frac{u_{i}^{\star} p r_{i, i}}{p r_{i, n}} k_{i}^{\star}\left(\left(1-\theta_{h}\right) W_{i}-G^{T}\right) \ldots \\
& \cdots+\frac{u_{w}^{\star} p r_{w, i}}{p r_{w, n}} k_{w}^{\star}\left(\left(1-\theta_{h}\right) W_{w}-G^{T}\right)+G^{T} \bar{N}+r_{B}\left(\lambda_{h, 0}+\lambda_{h, 1} r_{b}\right) \frac{1-\alpha_{h, 1}}{\alpha{ }_{h, 2}} D_{h}^{\star} \\
& Y D_{h}^{\star}\left(1-r_{b}\left(\lambda_{h, 0}+r_{b} \lambda_{h, 1}\right) \frac{1-\alpha_{h, 1}}{\alpha_{h, 2}}\right)=\frac{u_{e}^{\star} p r_{e, i}}{p r_{e, n}} k_{e}^{\star}\left(\left(1-\theta_{h}\right) W_{e}-G^{T}\right)+\frac{u_{i}^{\star} p r_{i, i}}{p r_{i, n}} k_{i}^{\star}\left(\left(1-\theta_{h}\right) W_{i}-G^{T}\right) \ldots \\
& p r_{w, n}
\end{aligned}
$$

e. Wealth, Income, and Consumption-Capitalists

$$
\begin{aligned}
C_{c a}^{\star} & =Y D_{c a}^{\star} \\
Y D_{c a}^{\star} & =\frac{\alpha_{c a, 2}}{1-\alpha_{c a, 1}} V_{c a}^{\star} \\
B_{c a}^{\star} & =\left(\lambda_{c a, 0}+\lambda_{c a, 1} r_{b}\right) V_{f c a}^{\star} \\
V_{c a}^{\star} & =(1-\lambda) p_{k}^{\star}\left(k_{e}^{\star}+k_{i}^{\star}+k_{w}^{\star}\right)+V_{f c a}^{\star} \\
F_{e}^{\star}+F_{i}^{\star}+F_{w}^{\star} & =r_{s} p_{k}^{\star}\left(k_{e}^{\star}+k_{i}^{\star}+k_{w}^{\star}\right) \\
F_{b}^{\star} & =r_{l} \lambda p_{k}^{\star}\left(k_{e}^{\star}+k_{i}^{\star}+k_{w}^{\star}\right)+r_{b} B_{b}^{\star} \\
B_{b}^{\star} & =M_{h}^{\star}+M_{c a}^{\star}-\lambda p_{k}^{\star}\left(k_{e}^{\star}+k_{i}^{\star}+k_{w}^{\star}\right) \\
M_{h}^{\star} & =V_{h}^{\star}-B_{h}^{\star} \\
M_{c a}^{\star} & =V_{f c a}^{\star}-B_{c a}^{\star} \\
Y D_{c a}^{\star} & =\left(1-\theta_{c a}\right)\left(p_{k}^{\star}\left(r_{s}+r_{l} \lambda\right)\left(k_{e}^{\star}+k_{i}^{\star}+k_{w}^{\star}\right)+r_{b} B_{b}^{\star}\right)+r_{b} B_{c a}^{\star} \\
& =\left(1-\theta_{c a}\right)\left(p_{k}^{\star}\left(r_{s}+\lambda\left(r_{l}-r_{b}\right)\right)\left(k_{e}^{\star}+k_{i}^{\star}+k_{w}^{\star}\right)+r_{b}\left(M_{h}^{\star}+M_{c a}^{\star}\right)\right)+r_{b} B_{c a}^{\star}
\end{aligned}
$$

